\title{
"To End the Degeneration of a Nation": Debates on Eugenic Sterilization in Inter-war Romania
}

\author{
MARIUS TURDA*
}

\section{Introduction}

Among various programmes of biological engineering developed in the twentieth century eugenic sterilization is one of the most notorious. The reasons are numerous, ranging from its application under the Nazi regime to its post-1945 application in the Scandinavian countries, the recent sterilization of the Roma in the Czech Republic, and China's birth planning policies. ${ }^{1}$ Yet it is only in the past two decades that our knowledge about sterilization policies and practices has improved-both in their historical context, and with respect to their practical implementation. ${ }^{2}$

After the First World War, the prospect of introducing coercive eugenic measures gained acceptance, especially in Northern and Western Europe. Within the economic

\section{(C) Marius Turda 2009}

* Marius Turda, PhD, RCUK Academic Fellow in Biomedicine, Department of History, Oxford Brookes University, Gipsy Lane, Headington Campus, Oxford OX3 0BP, UK; e-mail: mturda@brookes.ac.uk

Research for this article would not have been possible without financial support from the Wellcome Trust and Oxford Brookes University, and the wonderful assistance of Mioara Georgescu at the Library of the National Institute of Hygiene in Bucharest. I also want to thank Răzvan Pârâianu and Valentin-Veron Toma for helping me locate documents and articles in Romanian libraries and archives. Finally, I would like to thank Gisela Bock for her comments and suggestions, and the anonymous referees whose constructive criticisms have helped clarify many obtuse arguments. Responsibility for the views expressed here, however, is mine. All translations from the Romanian are also mine, unless otherwise specified.

\footnotetext{
${ }^{1}$ For the Scandinavian countries, see Maija Runcis, Steriliseringar i folkhemmet, Stockholm, Ordfront, 1998; Gunnar Broberg and Mattias Tydén, Ö̈nskade $i$ folkhemmet: rashygien och sterilisering $i$ Sverige, 2nd ed., Stockholm, Dialogos, 2005; Gunnar Broberg and Nils Roll-Hansen (eds), Eugenics and the welfare state: sterilization policy in Denmark, Sweden, Norway and Finland, 2nd ed., East Lansing, Michigan State University Press, 2005; Lene Koch, 'Eugenic sterilisation in Scandinavia', The European Legacy, 2006, 11 (3): 299-309; and Niels Lynöe, 'Race enhancement through sterilization: Swedish
}

experiences', Int. J. Mental Health, 2007, 36 (1): 17-25. For the sterilization of the Roma in the Czech Republic, see Mindy Kay Bricker, 'Sterilization of Czech Gypsies continues: eugenics policy dates back to Soviet era', posted on 12 June 2006 on RomNews Network Community @ RomNews.de (accessed 17 June 2008). For the situation in China, see Susan E Short, Ma Linmao, and Yu Wentao, 'Birth planning and sterilization in China', Population Studies, 2000, 54 (3): 279-91; and Frank Dikotter, Imperfect conceptions: medical knowledge, birth defects and eugenics in China, London, Hurst, 2000.

${ }^{2}$ Much of the credit for opening this field of research should be given to Gisela Bock's Zwangssterilisation und Nationalsozialismus: Studien zur Rassenpolitik und Frauenpolitik, Opladen, Westdeutscher Verlag, 1986. Among the most recent studies, see Mark A Largent, Breeding contempt: the history of coerced sterilization in the United States, New Brunswick, Rutgers University Press, 2008; Gisela Bock, 'Nationalsozialistische Sterilisationpolitik', in Klaus-Dietmar Henke (ed.), Tödliche Medizin im Nationalsozialismus. Von der Rassenhygiene zum Massenmord, Cologne, Böhlau, 2008, pp. 85-99; Yolanda Eraso, 'Biotypology, endocrinology, and sterilization: the practice of eugenics in the treatment of Argentinian women during the 1930s', Bull. Hist. Med., 2007, 81 (4): 793-822; Anna Stubblefield, "Beyond the pale": tainted whiteness, cognitive disability, and eugenic sterilization', Hypatia, 2007, 22 (2): 162-81; and Natalia Gerodetti, 'From science to social technology: eugenics and politics in twentieth-century

Switzerland', Social Politics: International Studies in Gender, State and Society, 2006, 13 (1): 59-88. 


\section{Marius Turda}

crises and political instability that characterized the late 1920 s, eugenic sterilization attracted considerable attention from both the medical profession and social reformers interested in protecting the nation from alleged biological degeneration and social decline. ${ }^{3}$ Many of their justifications were then taken over by intellectuals and government officials, and used in support of the biopolitical projects of the 1940s. Supporters of eugenic sterilization maintained that they were rendering the utmost service to society: defending future generations from social and biological degeneration. Whether such authors thought in terms of purifying the nation of "defective genes", or protecting it from mixing with "racially inferior" elements, there was widespread agreement that sterilization practices were necessary.

The extensive acceptance of eugenic sterilization is also reflected in its geographical diffusion: it was as passionately debated in Britain, the United States and Germany as in Brazil, Poland and Romania. Yet, while the Western European, North American and Latin American cases are well researched, little is known about debates in Eastern European countries. ${ }^{4}$ As Maria Bucur, Kamila Uzarczyk and Magdalena Gawin suggest, the history of eugenics in Eastern Europe has not only been unfairly neglected but has much to offer in terms of understanding the connection between science, political ideals and national contexts. ${ }^{5}$ This article hopes to enrich this emerging scholarship by concentrating on a hitherto neglected topic: eugenic sterilization in inter-war Romania.

The Romanian case meaningfully demonstrates the increasingly intertwined relationship between eugenic sterilization as medical praxis and eugenic sterilization as political discourse geared towards the political engineering of a biologically defined community. This relationship came about as a result of both international and domestic circumstances, including the wide diffusion of eugenic ideas throughout most European countries and the US following the First World War. The practices of sterilization in these countries indicate an overwhelming preoccupation with women's reproductive rights, combined with concerns about social categories such as criminals and/or medical categories such as the mentally ill. In inter-war Romania, on the other hand, debates on eugenic sterilization were predominantly stimulated by a particular fear of the degeneracy of the Romanian nation. For many supporters of sterilization, the concept of the nation served as a unifying principle linking their preoccupation with hygiene to concepts of eugenics, social progress and economic sustainability. Not to inquire into the

\footnotetext{
${ }^{3}$ See Paul Weindling, 'International eugenics: Swedish sterilization in context', Scand. J. Hist., 1999, 24 (2): 179-97.

${ }^{4}$ The only existing studies are Béla Siró, 'Eugenikai törekvések az ideg- és elmegyógyászatban Magyarországon a két világháború között', Orvosi Hetilap, 2003, 144 (35): 1737-42; Magdalena Gawin, 'Polish psychiatrists and eugenic sterilization during the inter-war period', Intern. J. Ment. Health, 2007, 36 (1): 67-78; and Kamila Uzarczyk, 'War against the unfit: eugenic sterilization in German Silesia, 1934-1944: sine ira et studio (without anger and bias)', Int. J. Ment. Health, 2007, 36 (1): 79-88.

${ }^{5}$ Maria Bucur, Eugenics and modernization in inter-war Romania, University of Pittsburgh Press,
}

2002; Kamila Uzarczyk, Podstawy ideologiczne higieny ras i ich realizacja na przykladzie Ślaska $w$ latach 1924-1944, Toruń, Wydawnictwo Adam Marszatek, 2003; and Magdalena Gawin, Rasa $i$ nowoczesność: historia polskiego ruchu eugenicznego, 1880-1952, Warsaw, Wydawnicwo Neriton, 2003; and idem, 'The sex reform movement and eugenics in interwar Poland,' Stud. Hist. Phil. Biol. Biomed. Sci., 2008, 39 (2): 181-6. For a broader regional perspective, see Marius Turda and Paul Weindling (eds), Blood and homeland: eugenics and racial nationalism in central and southeast Europe, 1900-1940, Budapest, Central European University Press, 2007. 


\section{Debates on Eugenic Sterilization in Inter-war Romania}

debate on sterilization would not only render the history of Romanian eugenics during the inter-war period incomplete but would also leave the relationship between concepts of national health and totalitarian biopolitics unexplored.

\section{Eugenic Sterilization as Medical Praxis}

The first sustained discussion on eugenic sterilization in Romania took place in the 1920s. ${ }^{6}$ Romanian eugenicists followed developments in the United States and Germany, in particular, and articulated many of their arguments in accordance with the sterilization models they emulated. In 1921, the deputy-director of the Social Insurance Central Bank in Bucharest, Dr Ioan Manliu, published Crâmpeie de eugenie şi igienă socială (Fragments of Eugenics and Social Hygiene). ${ }^{7}$ Manliu had studied medicine in Germany with the renowned paediatrician Carl Noeggerath, receiving a doctorate from the University of Freiburg in 1914. Claiming that he had studied "racial hygiene since 1912", 8 Manliu was a supporter of North American eugenics, a movement he examined at great length, admiring the fact that in the US, "The selection of individuals is performed through sterilization, regulation of immigration and emigration, isolation (deportation of antisocial elements) and schooling". 9 Familiar with surgical techniques like vasectomy and salpingectomy as well as with the activities of Harry Sharp—who, in 1899, pioneered the sterilization of criminals by vasectomy at the Indiana State Reformatory-Manliu proposed the following:

1) Every degenerate individual should be sterilized and, if possible, returned to society. 2) Every degenerate and sterilized individual should be kept in isolation in asylums and colonies until he/she can be returned to society as a useful member. 3) Only those individuals who still pose a danger to society after their sterilization should be isolated for life, while they should sustain themselves and society through work in gardens, workshops, etc. ${ }^{10}$

It was this interventionist eugenic programme that Manliu hoped to apply to Romania. "It is in this direction", he added, "that we must orient our efforts to protect superior elements and prohibit without mercy inferior elements from producing children and incurring family responsibilities." The only way to regain control over the body of the nation, he concluded, was the "mass sterilization of degenerates". ${ }^{11}$

Manliu remained actively involved in the ensuing debates on eugenic sterilization, returning to the subject in a 1923 article published in one of the most important Romanian

\footnotetext{
${ }^{6}$ The gynaecologist Constantin Andronescu suggested the introduction of prenuptial health certificates and the sterilization of feeble-minded and mentally ill people as early as 1912 . See his 'Eugenia', Higiena, 1912, 1 (21): 4.

${ }^{7}$ Ioan Manliu, Crâmpeie de eugenie şi igienă socială, Bucharest, Tip. 'Jockey-Club', 1921.

8 "Subsemnatul doctor în medicină, cu examen de stat din Germania, care m-am ocupat din anul 1912 special de igiena de rasă." See Manliu's letter (dated $1920)$ to the Ministry of Work and Social Protection. Manliu, Ioan, Personal File. Archive of Ministry of Health, Bucharest.

9 "Selecţionarea indivizilor se face prin sterilizare, reglementarea imigrării şi emigrării, prin izolare
}

(deportarea elementelor rele) şi şcoală." Manliu, op. cit., note 7 above, p. 18 .

10 "1) Orice individ degenerat trebuie sterilizat şi, de se poate, să fie redat societăţii. 2) Orice individ degenerat şi sterilizat, trebue să ramâe izolat în azile sau colonii, până va putea fi redat societăţii ca element folositor. 3) Izolarea pe viaţă să se facă numai la acei indivizi, ce rămân şi după sterilizare periculoşi societăţii, cătând a exploata energia lor cât mai mult pentru întreţinerea lor şi pentru societate, în grădini, ateliere, etc." Ibid., p. 21 .

11 “Sterilizări în masă la cei degeneraţi." Ibid. 


\section{Marius Turda}

newspapers of its time, Adevărul (The Truth). Within general European concerns about natalism and population policy, the newspaper accommodated a debate on abortion and birth control with the hope of clarifying some of the uncertainties surrounding sexual reproduction. ${ }^{12}$ As was to be expected, two contradictory points of view emerged. The first, supported by the surgeon Constantin Poenaru-Căplescu, was against abortion; the other, articulated by the director of propaganda in the Ministry of Work and Health, Iosif Glicsman, writing under the pseudonym Dr Ygrec, endorsed it. ${ }^{13}$ Manliu sided with those rejecting the legalization of abortion, considering it a "crime". 14

Convinced that abortion would endanger the biological prosperity of the nation, Manliu further demanded that the state improve medical and welfare measures for "illegitimate" children, while public opinion should de-stigmatize unmarried mothers. Like the German gynaecologist Max Hirsch-who referred to illegitimate children as Staatskinder (state children) ${ }^{15}$-Manliu declared that each "newborn belongs to the entire nation". 16 Such an innovative concept of guardianship did not, however, apply to children considered "hereditarily inferior". Manliu considered this category "worthless". "The nation does not need them", he maintained, arguing: "We are not going to encourage degenerate mothers to abort their children but we are going to act more radically: we will sterilize them. We will try to introduce this procedure in our country as soon as possible, for both degenerate women and men."17

This debate on abortion serves as an indicator of the evolution of perceptions of sterilization in the 1920s. If Manliu was mainly preoccupied with the North American model of eugenics, the discussion now broadened to include Germany and France. As noted by Gisela Bock with regard to German racial hygiene, the campaign for sterilization took a new, more vigorous turn by the end of First World War. It was then that "German aggrandizement and stability seemed at its lowest", and that "sterilization was widely and passionately recommended as a solution to urgent social problems". ${ }^{18}$ Dr Ygrec, for instance, informed his readers of the sterilization debate in Saxony, drawing on the report presented by the criminologist Erich Wulffen to the Landrat of Saxony. Wulffen's report

\footnotetext{
${ }^{12}$ For the French case, see William H Schneider, Quality and quantity: the quest for biological regeneration in twentieth-century France, Cambridge University Press, 1990; for the British case, see Richard A Soloway, Demography and degeneration: eugenics and the declining birthrate in twentiethcentury Britain, Chapel Hill, University of North Carolina Press, 1990; for the German case, see Atina Grossmann, Reforming sex: the German movement for birth control and abortion reform, 1920-1950, Oxford University Press, 1995.

${ }^{13}$ See, for example, Ygrec, 'O problemă importantă: Păreri din public în chestiunea provocatorilor şi a provocărilor de avorturi', Adevărul, 1923, 36 (12141): 1-2; C PoenaruCăplescu, 'Medicii avortori şi făcătoarele de îngeri!', Adevărul, 1923, 36 (12144):1-2; and Ygrec, 'Iarăşi despre avorturi provocate şi medicii avortori', Adevărul, 1923, 36 (12152): 1-2.
}

\footnotetext{
${ }^{14}$ I Manliu, 'Un pericol social', Adevărul, 1923, 36 (12135): 1-2.

${ }^{15}$ Paul Weindling, Health, race and German politics between national unification and Nazism 1870-1945, Cambridge University Press, 1989,

16 "Copilul care se zămisleşte e bunul națiunei întregi." Manliu, op. cit., note 14 above, p. 2.

17 "Naţiunea nu are nevoie de ei. De aceea numai pe aceştia îi vom opri să aducă pe lume copii; nu vom avorta aceste mame ci vom proceda mai radical: le vom steriliza. Şi vom căuta să introducem această operaţie cât mai curând în ţara noastră, atât la femeea cât şi la bărbatul degenerat." Ibid.

${ }^{18}$ Gisela Bock, 'Racism and sexism in Nazi Germany: motherhood, compulsory sterilization, and the state', Signs: Journal of Women in Culture and Society, 1983, 8 (3): 400-21, on p. 404.
} p. 189. 


\section{Debates on Eugenic Sterilization in Inter-war Romania}

on sterilization-as drafted by Gustav Boeters, "the sterilization apostle"19 — favoured radical eugenic measures, arguing that criminals, so-called idiots, the feeble-minded, epileptics, the blind, deaf and dumb should all be sterilized, together with women and girls who gave birth to more than one illegitimate child. ${ }^{20}$

Equally important were the technical details concerning sterilization offered by Dr Ygrec-most probably in an attempt to familiarize the Romanian public with this surgical procedure. "Sterilization", he explained, "is not castration, but an operation which does not extirpate the sexual glands (testicles and ovaries), but cuts a small portion from the tube [the vas] which carries ovules and spermatozoids to the genital organs." ${ }^{21}$ The distinction between sterilization and castration was important, not least because the first reported sterilizations in the United States were accomplished by castration, a practice with strong negative connotations. ${ }^{22}$ Indeed, it was only after the rediscovery of Mendel's theories of inheritance in 1900, and the standardization of surgical procedures like vasectomy and salpingectomy, that sterilization in the US received general acceptance. $^{23}$

That Ygrec subtly endorsed German ideas of eugenic sterilization did not escape the attention of some of his readers. A prompt reaction came from the psychiatrist and neurosurgeon Dimitrie Bagdasar. In supporting the opposite view, Bagdasar resorted to the arguments put forward by the French psychiatrist Roger Mignot in his studies on morbid heredity and polygamy. ${ }^{24}$ Subscribing to Mignot's scepticism about a direct correlation between morbidity and heredity, Bagdasar argued that "repeated sterilizations could only lead to the numerical reduction of the race but would not guarantee its future improvement, not even a relative one". ${ }^{25}$ Yet, if Bagdasar expressed doubts about negative eugenic practices like compulsory sterilization, this was because he believed that the current state of medical knowledge provided inconclusive results on the heredity of many degenerative diseases. Without a clearly established link between heredity and biological degeneration, Bagdasar contended, physicians should abstain from endorsing the sterilization of those suffering from mental illnesses.

Bagdasar's invocation of French psychiatry was not accidental. It was customary for Romanian physicians, especially from the Kingdom of Romania, to receive their medical education in France and, consequently, they were influenced by French medical practices

\footnotetext{
${ }^{19}$ Weindling, op. cit., note 15 above, p. 389.

${ }^{20}$ Doctorul Ygrec, 'Cum vor nemţii să-şi îmbunătățească rasa? Se cere sterilizarea celor anormali, a epilepticilor, surdo-muţilor, demenţilor etc.', Adevărul, 1923, 36 (12143): 1. For the German context, see Weindling, op. cit., note 15 above, pp. 388-93; and Michelle Mouton, From nurturing the nation to purifying the volk: Weimar and Nazi family policy, 1918-1945, Cambridge University Press, 2007, pp. 107-52.

21 "Prin sterilizare nu se înțelege castrare, ci o mică operaţie care nu extirpează glandele sexuale (testiculele şi ovarele), ci taie o mică porţiune a canalelor care duc ovulele şi spermatozoizii spre organele genitale." Ygrec, op. cit., note 20 above, p. 1.
}

\footnotetext{
${ }^{22}$ Daniel J Kevles, In the name of eugenics: genetics and the uses of human heredity, Cambridge, MA, Harvard University Press, 1995, p. 108.

${ }^{23}$ S Manuilă, 'Sterilizarea eugenică în Statele Unite', România de mâine, 1924, 1 (24): 484.

${ }^{24}$ See Roger Mignot, 'Enquête sur la fréquence des troubles mentaux dans le personnel des asiles d'aliénés', Annales Médico-psychologiques, 1905, 2 (1): 22-8.

25 "Procedând atunci la sterilizări repetate, acestea ar avea drept rezultat o scădere numerică a rasei, fără să putem fi siguri de o îmbunătătire măcar şi relativă a ei în viitor." D Bagdasar, 'Sterilizarea', Adevărul, 1923, 36 (12170): 1.
} 


\section{Marius Turda}

and ideas. ${ }^{26}$ In post-First World War Romania, however, neo-Lamarckian interpretations of social and biological degeneration-which still found supporters among many French health reformers and eugenicists—receded. ${ }^{27}$ Unlike Argentina, for example, where-as Yolanda Eraso has noted-eugenicists "loyal to the Latin tradition of France and Italy [embraced] the theory of constitution or biotypology", ${ }^{28}$ in Romania the predominant view was rather that of biological determinism, upholding the idea that individual traits were transmitted from generation to generation independent of the environment.

This increased acceptance of explanations for degeneration based on heredity and genetics occurred in the wake of a wider focus on national projects of ethnic protectionism. The notion that there was a strong relationship between dysgenic individuals and the broader community - the nation-emerged during this period. In 1925, the prominent eugenicist and founder of the School of Hygiene and Public Health in Cluj (Transylvania), Iuliu Moldovan, published Igiena naţiunii: eugenia (The Hygiene of the Nation: Eugenics), in which he defined "the nation as a biological reality, a human structure with its specific biology and pathology". ${ }^{29}$ Correspondingly, eugenics was closely connected to state interventionism and radical measures to regulate health, including "preventing defective individuals from procreating". ${ }^{30}$ Moldovan placed the family at the centre of his theory of national eugenics, and envisioned measures to protect it from both social and biological threats. No medical prophylactic method, however, Moldovan claimed, could be efficient unless the population-and especially those affected by diseases - acquired "a racial consciousness, a sentiment of biological responsibility". "What should unite the members of the community was not merely a cultural and political ideology, but a new fusion of nationalist and eugenic ideals.

Connected to this argument were Moldovan's observations on sterilization legislation in the US, which was commended as a "splendid document of the courage and healthy reasoning of the American people". 32 Yet, in Romania-Moldovan complained-"humanitarianism" prevailed over the "superior biological interests of the nation". 33 By criticizing the liberal "humanitarianism" of the Romanian political elites, Moldovan addressed the lack of state support for eugenics. His grievance thus has to be read against the background of debates between the new political elite originating from the provinces and the political interest groups in Bucharest over the most appropriate method for protecting the Romanian majority in the new state created in

\footnotetext{
${ }^{26}$ For a discussion of this aspect, see Gheorghe Brătescu and Klaus Fabritius, Biological and medical sciences in Romania, Bucharest, Ştiinţifică şi

Enciclopedică, 1989.

${ }^{27}$ For the influence of neo-Lamarckism on French eugenics, see Schneider, op. cit., note 12 above, pp. 55-83.

${ }^{28}$ Eraso, op. cit., note 2 above, p. 798.

29 "Naţiunea este deci o realitate biologică, o formaţ̧iune umană cu biologia şi patologia ei specifică.” I Moldovan, Igiena naţiunii (Eugenia), Cluj, Institutul de Igienă şi Igienă Socială, 1925, p. 12.

30 "[T] rebuie să intervenim în mod conştient, eliminând întrucât e posibil dela procreaţie indivizii defectuoşi.” Ibid., p. 37.
}

\footnotetext{
31 “"[C]hezăşia rezultatului zace în primul rând în disciplina celor interesaţi, o disciplină susţinută în afară de cunoştiinţele necesare, îndeosebi de conştiinţa de rasă, de sentimental de răspundere biologică." Ibid., p. 46.

32 “" $[\mathrm{E}] \mathrm{a}$ rămâne un document splendid de curajul şi raţionamentul sănătos al poporului american." Ibid., p. 47.

33 "Este un nou domeniu, unde se ciocneşte umanitarismul cu interesele superioare ale naţiunii şi unde aceasta se află într-o stare de dureroasă inferioritate." Ibid., p. 48.
} 


\section{Debates on Eugenic Sterilization in Inter-war Romania}

1918; a state which accommodated numerous ethnic minorities, and regions with different historical traditions. ${ }^{34}$ Political leaders from Transylvania and other provinces felt marginalized by politicians from the Old Kingdom, and Moldovan often expressed such anxieties whenever his eugenic ideas met with reticence in Bucharest. ${ }^{35}$

In 1927, Romania's most important eugenic journal Buletin Eugenic şi Biopolitic (Eugenics and Biopolitics Bulletin) entered the debate and immediately began encouraging submissions on eugenic sterilization. The first was the translation of an article written especially for the journal by the leading supporter of eugenic sterilization, Harry Laughlin, the deputy director of the American Eugenics Record Office. Based on Laughlin's public successes in advising various sterilization committees in the US (including that investigating the famous Carrie Buck case in Virginia), the editorial committee introduced Laughlin as "the most appropriate person to express opinions on eugenics, and especially on its practical application". ${ }^{36}$ For his Romanian audience, Laughlin presented a short history of sterilization legislation in the US and concluded it with excerpts from his 1922 Eugenical sterilization in the United States, including a description of the "cacogenic person" and Section 3 describing the "Office of State Eugenicist". 37

Laughlin's text was followed by a discussion of the famous sterilization case of Alice Smith, an inmate of the State Village for Epileptics at Skillman, New Jersey, ${ }^{38}$ offered by Mihai Zolog, assistant professor at the Institute of Hygiene and Public Health in Cluj. Reflecting his interest in social hygiene and welfare improvement, Zolog linked eugenic sterilization not only to the health of the individual but also to the welfare of the race, outlining its "penal, therapeutic, and eugenic" roles, and insisting that "sexual sterilization should have a solely eugenic goal, as the sterilization of a person can only be justified for one reason: to improve the biological qualities (physical, intellectual and moral) of future generations". 39

By the late 1920s, support for eugenic sterilization had grown. To be sure, Romanian eugenicists continued to argue for improvements in education, housing and public health as prerequisites for a healthy nation, but supporters of eugenic sterilization regarded these methods as ineffective, representative of a transitional phase in the history of medical sciences that would inexorably be replaced by a new scientific ethos, based on eugenics.

\footnotetext{
${ }^{34}$ See Irina Livezeanu, Cultural politics in Greater Romania: regionalism, nation building, and ethnic struggle, 1918-1930, Ithaca, NY, Cornell University Press, 1995.

${ }^{35}$ In 1922 Moldovan was accused of spending state funds on personal projects. The accusation proved false but Moldovan considered the scandal to be an attempt by the liberal regime in Bucharest to taint his reputation. See Bucur, op. cit., note 5 above, pp. 29-30; and Iuliu Moldovan, Amintiri şi reflexii, Bucharest, Ed. Carol Davila, 1996, pp. 57-60.

36 "Dr. Harry H. Laughlin este cel mai indicat de aş spune cuvântul în materie de eugenie şi mai cu seamă în ceea ce priveşte aplicarea practică a acestei ştiinţe.” Harry Laughlin, 'O privire asupra sterilizării
}

eugenice în America', Buletin Eugenic şi Biopolitic, 1927, 1 (9-10): 253-7, on p. 257.

${ }^{37}$ Harry Laughlin, Eugenical sterilization in the United States, Chicago, Psychopathic Laboratory of the Municipal Court of Chicago, 1922, pp. 447-51.

${ }^{38}$ Frances Oswald, 'Eugenical sterilization in the United States', Am. J. Sociol., 1930, 36 (1): 65-73, on p. 68 .

39 “Aici accentuăm încă odată, că sterilizarea unei persoane se poate reclama numai sub un singur motiv: îmbunătătirea calităţilor biologice (fizice, intelectuale şi morale) a generaţiilor viitoare." M Zolog, 'Un caz indicat pentru sterilizare eugenică', Buletin Eugenic şi Biopolitic, 1927, 1 (11-12): 326-33, on p. 326. 


\section{Marius Turda}

\section{A New Eugenic Ethos}

A new sanitary law was introduced in Romania in 1930, expressing the ideas of social hygiene and public health of its architect Iuliu Moldovan, at the time sub-secretary of state in the Ministry of Work, Health and Social Protection. Bucur has extensively discussed Moldovan's eugenic ideas in relation to his related sanitary law, concluding that "because Romanian eugenicists overall did not favour sterilization as a tool for generating eugenic betterment, this [sanitary] law did not include any such measures". ${ }^{40} \mathrm{My}$ contention, however, is that the majority of Romanian eugenicists were, in fact, in agreement that eugenic sterilization would contribute decisively to reducing the number of those considered mentally and socially degenerate. That such a requirement was not introduced in the 1930 law had more to do with political factors, like the above mentioned liberal "humanitarianism" of the Romanian political elite, than with Moldovan's rejection of eugenic sterilization. That eugenics served, in fact, as one of the guiding principles of the law is evident from the regulation of abortion. Thus, according to paragraph 9: "Abortion could be carried out only for eugenic and social reasons, determined by a commission of specialists and approved-in social cases-by the responsible local officials". ${ }^{41}$ Contrary to its negative approach to abortion in general, the 1930 law permitted it on eugenic grounds; yet because eugenic sterilization pushed the boundaries of state interference in the life of the individual beyond the mere termination of a pregnancy, it required additional support from both the scientific community and the political establishment.

Just a year after the law was promulgated, Manliu asserted in a much bolder way the need for eugenic sterilization. "How can we fight degeneration?" His answer was as unequivocal as was his question: "By stopping the reproduction of degenerates and encouraging the fertility of superior individuals." 42 Manliu envisioned several methods for neutralizing the proliferation of "degenerate individuals". The first, "life imprisonment", was deemed impracticable due to its high social cost; others, such as the prohibition of marriage, abortion or the use of birth-control techniques, he considered difficult to put into practice. Once more, it was eugenic sterilization that Manliu favoured.

This time, he envisioned a racial crusade against national degeneration. He indicated a wide range of individuals, affected by social and clinical conditions, who should be sterilized, including psychopaths, epileptics, criminals, and alcoholics, those suffering from haemophilia or cancer, as well as the "remarkably ugly". Manliu translated his personal fears of biological degeneration into a national crisis, broadening the reasons for eugenic sterilization to include anyone deemed injurious to the body of the nation: "From the

\footnotetext{
${ }^{40}$ Bucur, op. cit, note 5 above, p. 3. See also Maria Bucur, 'Romania', in Kevin Passmore (ed.), Women, gender and Fascism in Europe, 1919-45, Manchester University Press, 2003, pp. 57-78.

41 "Avortul poate fi efectuat numai pe motive eugenice şi sociale, stabilite de o comisie de specialişti şi aprobate, atunci când e vorba de motive sociale, de autorităţile locale responsabile." Sabin Manuilă, "Principiile de bază de ocrotirii mamei şi
}

copilului. Art 9 Reglementarea avortului. Represiuni şi indicaţiuni." Manuilă, Sabin, Personal File. Archive of Ministry of Health, Bucharest.

42 "Oprind reproducerea degeneraţilor şi cultivând fertilitatea la indivizii superiori." I Manliu, 'Sterilizarea degeneraților', Revista de Igienă Socială, 1931, 1 (5): 374-85, on p. 375 (emphasis in the original). 


\section{Debates on Eugenic Sterilization in Inter-war Romania}

sterilization of a few thousand individuals, interned or free, one cannot expect a transformation of our hereditary constitution. To end the degeneration of a nation we need to sterilize en masse."43

Dramatic though the escalation of Manliu's eugenic rhetoric may have appeared, it was in fact neither new nor something confined to Romania. Eugenicists in both the United States and Germany expressed similar positions on this issue. Quoting Laughlin, for instance, who claimed that " 10 per cent of each generation should be sterilized in order to obtain practical results", as well as the German social hygienist Alfred Grotjahn, who considered "a third of the [German] population to be inferior", ${ }^{44}$ Manliu proposed that, in the Romanian case, "we should sterilize $5^{1 / 2}-6$ million". 45 How to implement such a radical plan in Romania? As a basic practical measure, he continued unabatedly,

Sterilization should be declared legal in all prisons; mental asylums; schools for juvenile delinquents; colonies of vagabonds; and for homeless people found during police raids, etc. For other abnormal, free individuals (psychopaths, the mentally insane, alcoholics, etc.) sterilization must be conducted at their request and initiated immediately without the need for a special law. It is sufficient to have the consent of the person on whom the operation is performed. ${ }^{46}$

As far as medical prerogative was concerned, Manliu elevated the role of the doctor to that of ultimate authority. Sterilization would be performed "only after [the patients] have been examined by at least two doctors (one for internal, the other for mental illnesses) and found that they exhibit the probability of producing degenerate offspring". 47

It was in the name of scientific progress, and as a means for Romania to acquire international recognition that Manliu celebrated eugenic sterilization: "If Romania contributed nothing else to the solution of the problems of human biology, she could at least now sterilize 10,000 degenerates in one year in order to gain much practical experience which would contribute greatly to the spread of this principle throughout the rest of Europe." 48

Like other eugenicists, Manliu believed that Romanian society at the time was dominated by a liberal egalitarianism that was detrimental to the future of the nation. This ideology needed to be replaced by a new eugenic ethos, and he appealed to the schools, the Church, the judicial system, the administration, and the army to contribute to the

\footnotetext{
43 "Dela sterilizarea câtorva mii de indivizi, internaţi sau liberi, nu se poate aştepta o schimbare a constituţiei noastre ereditare. Pentru a opri degenerarea unei națiuni, trebuie să sterilizăm $\hat{\imath n}$ massă." Ibid., p. 378 (emphasis in the original).

${ }^{44}$ Ibid.

${ }^{45}$ Ibid., p. 381 (emphasis in the original).

46 "Ca început practic, sterilizarea va trebui decretată la noi în toate închisorile, casele de nebuni, şcolile de corecţie, de arieraţi, colonii de vagabonzi, la oamenii fără căpătâi, găsiţi cu ocazia raziilor făcute de poliţie, etc. La toţi ceilalţi anormali, liberi (psychopați, debili mentali, alcoolici, etc.) sterilizarea trebuie admisă la cererea lor şi practicată
}

de pea cum, fără vre-o lege specială. E sufficient consimţământul celui ce vrea să se opereze." Ibid.

47 "Bineînţeles, după ce au fost examinaţi de doi medici cel puţin (unul de maladii interne, altul de maladii mentale) şi găsiţi că prezintă probabilitatea de progenitură degenerată." Ibid.

48 "Dacă România nu a contribuit cu nimic la rezolvarea problemelor de biologie umană, ar trebui cel puţin acum să facă primul pas decisive, operând 10,000 degeneraţi într-un an, spre a acumula o mare experienţă, care ar contribui mult la generalizarea acestui principiu în Europa întreagă." Ibid., p. 382 (emphasis in the original). 


\section{Marius Turda}

"biological rejuvenation" of the Romanian nation. That he enlisted the Orthodox Church to help disseminate eugenic thought is particularly important. Compared with the public announcements of the Catholic Church, including the 1930 papal encyclical Casti connubii (On Christian Marriage) that condemned negative eugenic methods such as abortion and sterilization, ${ }^{49}$ the Orthodox Church was ambivalent on the subject, and did not issue any equivalent official statements. ${ }^{50}$ This is not to say that some ecclesiastical journals did not voice their concern about eugenics, but this anxiety was never endorsed (or contested) by the prelates of the Orthodox Church. ${ }^{51}$

In a country where Orthodox Christians made up 72.6 per cent of the population, the Orthodox Church played an important role in all aspects of life. ${ }^{52}$ Whether Manliu's eugenic vision of an extensive biological transformation of Romanian society would be accepted was ultimately dependant on its support. Not surprisingly, then, Manliu called on the Church "to use its overwhelming moral authority, declare itself in favour of biological purification and act accordingly". ${ }^{53}$ Furthermore, he encouraged the Church to guide the eugenic transformation of Romanian society, arguing that:

The moment has come for [the Orthodox Church] to take part without delay in this [eugenic] movement, in order to ensure scientifically and biologically the happiness of its believers. If the Church firmly popularizes eugenic ideas and collaborates fanatically in their realization, it could provide an invaluable service in our struggle against the degeneration and Asiatization of our race. $^{54}$

Manliu had grasped the essential precondition for any project of social and biological engineering to succeed in Romania: its embrace by the Orthodox Church, or a state powerful enough to circumvent the authority of the religious hierarchy, as was the case in Nazi Germany (or, after 1947, in communist Romania). ${ }^{55}$ Predating some of the most extreme racially motivated eugenics, his conclusions echoed apocalyptic visions of biological degeneration. To avoid this dire eventuality, it was necessary, he proclaimed, that "the struggle against the inferior man must be aggressively maintained.

\footnotetext{
${ }^{49}$ See Etienne Lepicard, 'Eugenics and Roman Catholicism: an encyclical letter in context: Casti connubii, December 31, 1930', Science in Context, 1998, 11 (3-4): 527-44; and Monica Löscher,

'Eugenics and Catholicism in inter-war Austria', in Turda and Weindling (eds), op. cit., note 5 above, pp. 299-316; and Monika Löscher, 'Katholizismus und eugenik in Österreich. "... dass die katholische auffassung alle vernüftigen versuche der positiven eugenik voll freude begrüßt und unterstützt ...", in Gerhard Baader, Veronika Hofer, Thomas Mayer (eds), Eugenik in Österreich: biopolitischen strukturen von 1900-1945, Vienna, Czernin Verlag, 2007, pp. 140-61.

${ }^{50}$ See Mirel Banică, Biserica Ortodoxă Română. Stat şi societate în anii '30, Iaşi, Polirom, 2007, pp. $98-105$.

${ }^{51}$ See, for example, I D, 'Despre eugenie', Glasul Monahilor, 1936, 14 (482): 4.
}

\footnotetext{
${ }^{52}$ The statistical data is from Joseph Rothschild, East Central Europe between the two world wars, Seattle, University of Washington Press, 1974, p. 284.

53 "Biserica trebuie să facă uz de autoritatea morală covârşitoare, să se pronunţe afirmativ pentru epurarea biologică şi să treacă la fapte." Manliu, op. cit., note 42 above, p. 382.

54 “A sosit însă momentul ca să ia parte neîntârziat la această mişcare, pentru a asigura ştiinţific, biologic, în primul rand fericirea credincioşilor ei. Biserica ne poate aduce nepreţuite servicii în lupta noastră împotriva decăderii, asiatizării rasei noastre, dacă va propaga dârz ideile de eugenie şi va colabora fanatic la realizarea lor." Ibid., pp. 382-3.

${ }^{55}$ For the case of communist Romania, see Gail Kligman, The politics of duplicity: controlling reproduction in Ceausescu's Romania, Berkeley, University of California Press, 1998.
} 


\section{Debates on Eugenic Sterilization in Inter-war Romania}

Sterilization is one of the decisive factors in the extermination of sub-humans, and the biological ennoblement of mankind." 56

Eugenic sterilization and the extermination of dysgenic individuals were two principles at the heart of Manliu's biological philosophy. Indeed, he was the first to argue for widespread sterilization of the population. Yet, subsequent contributions to the debate on eugenic sterilization indicate that, at the time, he was acting as an isolated enthusiast, whose theoretical concerns and rhetorical usages were not shared by other Romanian eugenicists. Rather, most of them preferred to direct their attention at specific medical and social categories-especially the feeble-minded-than generalize about the racial future of the Romanian nation.

\section{Feeble-mindedness and Psychiatry}

Manliu's article was published in the newly established Revista de Igienă Socială (Review of Social Hygiene), edited by the social hygienist and public health reformer Gheorghe Banu. The journal emerged in the 1930s and 1940s as another important Romanian publication on eugenics, hygiene and social hygiene, one directly competing with Moldovan's Buletin Eugenic şi Biopolitic for scientific pre-eminence and readership. Shortly after Manliu's article, the Revista de Igienă Socială published another commentary on eugenic sterilization. Written by Mareş Cahane, a psychiatrist in Diciosânmărtin (today Târnăveni) in central Transylvania, this paper re-focused the sterilization debate on a specific category of individuals: the hereditarily feeble-minded.

As already shown, the social danger posed by mental disorders was constantly emphasized within Romanian discourses on eugenic sterilization. But fears of mental degeneracy might have been overstated, Cahane argued. According to one statistical analysis, in 1924 there were no more than 41,113 registered cases of patients suffering from mental disorders; that is 0.23 per cent of a population of almost 18 million. ${ }^{57}$ This low percentage clearly challenged Manliu's claim of the widespread biological degeneration of the Romanian nation.

To be sure, Cahane was no radical eugenicist, but, like other Romanian authors, he too was well read in the North American and European literature on eugenic sterilization, as indicated by his correspondence with the American eugenicist Ezra Gosney. In fact, Cahane based both his interpretation of the sterilization laws in the United States and the arguments about legislating for sterilization in Romania on Gosney and Popenoe's 1929 account of sterilization in California. Their thesis, namely that "Eugenic sterilization of the hereditary defective is a protection, not a penalty", 58 he applied to Romanian realities.

\footnotetext{
56 "Lupta contra omului inferior trebuie dusă cu înverşunare. Sterilizarea e unul dintre cei doi factori decisivi in exterminarea sub-omului şi aristocratizarea biologică a omenirii." Manliu, op. cit., note 42 above, p. 384 (emphasis in the original).

${ }^{57}$ I Glicsman, Boalele mintale în România (Statistica pe anul 1924), Bucharest, Socec, 1926. His
}

data was also used by G Banu in 'Înfăţişările speciale ale biologiei poporului român', Revista de Igienă Socială, 1935, 5 (12): 671-89, on p. 680.

${ }^{58}$ E S Gosney and Paul Popenoe, Sterilization for human betterment, New York, Macmillan, 1929, p. ix. 


\section{Marius Turda}

Cahane insisted that more attention should be devoted, first and foremost, to "legislating therapeutic sterilization", and that it should be limited "to [those suffering from] mental illnesses". 59 As a psychiatrist, Cahane interacted frequently with patients at the colony for the mentally ill in Diciosânmărtin, which he proudly described as "the Gheel colony of the Orient" after the famous institution for the insane in Belgium. One of the particular features of the Diciosânmărtin colony was its "open door" policy; the patients were allowed to leave the hospital, and lived and worked with peasants in the neighbouring village-which also benefited the local economy. Yet, this posed a serious problem, claimed Cahane, for the patients were "cacogenic elements", who could not control their sexuality. There were thirty-nine men and fifty-eight women between the ages of twenty and sixty diagnosed as feeble-minded, but there was "no data on the reproductive capacity of these patients". ${ }^{60}$ As expected, sterilization was envisaged as the most appropriate method to preserve the patients' economic contribution to society while rendering them biologically inoffensive.

Cahane cited this colony as a model for similar institutions to be created in Romania, a fact reiterated on the occasion of the XIth Congress of Neurology, Psychiatry, Psychology and Endocrinology held in Diciosânmărtin in 1931 under the presidency of Constantin Parhon, the founder of the Romanian school of endocrinology. It was also at this conference that Cahane addressed the issue of therapeutic sterilization of the hereditarily feeble-minded. The ensuing discussion attracted the participation of prominent Romanian psychiatrists, including Leon Ballif and Mircea Bruteanu. On the final day, the Congress adopted a motion according to which:

Members of the XIth Congress of the Society of Neurology, Psychiatry, Psychology and Endocrinology ... ask the ... Ministry of Health to accept as a prophylactic measure the sterilization of the hereditary feeble-minded by X-rays or vasectomy. This sterilization could be performed only on patients who have been interned for at least five years in a mental hospital and only after the advice of a commission of specialists and the consent of the family [have been obtained]. ${ }^{61}$

It is not difficult to see why, given his professional experience, Cahane suggested a careful examination and elaborate diagnosis of patients before sterilization was performed. Indeed, he repeatedly stressed the need to differentiate between therapeutic and voluntary sterilization. With respect to the first, Cahane acknowledged that for certain categories of the feeble-minded-schizophrenics, for instance-sterilization and castration should be compulsory. It was at this point in his paper that he mentioned that it was Parhon "who had applied therapeutic sterilization to a sexually deviant patient and to

\footnotetext{
${ }^{59}$ Mareş Cahane, 'Asupra sterilizării alienaţilor cronici. Necesitatea unei legiferări la noi', Revista de Igienă Socială, 1932, 2 (3): 241-9, on p. 243.

${ }^{60}$ Ibid., p. 246.

61 "Membrii celui de al XI-lea congres al Societăţii de neurology, psichiatrie, psichologie şi endocrinology ... roagă onor. Ministerul Sănătăţii ca
}

să admită ca măsură profilactică sterilizarea prin raze Röntgen sau vasectomie a acestor bolnavi cronici. Această sterilizare să poată fi exercitată numai asupra bolnavilor cronici cari au stat cel puţin 5 ani într-un spital de boli mintale şi numai după avizul unei comisiuni de specialişti şi cu consimţământul familiei." Ibid., p. 247. 


\section{Debates on Eugenic Sterilization in Inter-war Romania}

two epileptics" in Romania. ${ }^{62}$ Moreover, Cahane's recommendations for voluntary sterilization provided a safeguard against popular ignorance and misinterpretation: "This type of sterilization could be performed only when the cultural level of the public has advanced." ${ }^{63}$ Nevertheless, this moderate terminology obscures his commitment to eugenic sterilization. He thus concluded his discussion by stressing that directors of mental hospitals had a duty to persuade recovered patients of their need for sterilization, and to inform them of how disadvantaged their offspring would be. It was left to physicians and psychiatrists working in mental institutions to decide which methods of treatment were most suitable for their patients, a legal authorization that was-Cahane insisted-codified in the sanitary law of 1930 (Article 455). ${ }^{64}$

Yet, the motion on sterilization adopted by the Congress was not submitted to the Ministry of Health, Cahane admitted in $1935 .^{65}$ By then, he too had become more determined in his support of eugenic sterilization, arguing that legislation should be enacted for: "1. eugenic abortion; 2. voluntary sterilization; 3. the sterilization of those with chronic diseases according to the motion presented in 1931."66 Cahane acknowledged that, far from being satisfied with the existing situation, both the medical profession and the general public showed a marked reluctance to endorse eugenic sterilization. ${ }^{67}$

In the meantime, however, the general European trend was gravitating towards legislation on negative eugenics. Laws authorizing sterilization were introduced in Switzerland (1928), Denmark (1929), Germany (1933), Norway (1934), and Finland (1935). As a result, Romanian eugenicists began to promote their views more vigorously, particularly their commitment to sterilization. The debate also widened. Hitherto restricted to medical specialists, eugenic sterilization now increasingly attracted other categories of professionals, especially legal experts, sociologists, and statisticians.

\section{The Impact of the German Sterilization Law}

Both the Revista de Igienă Socială and the Buletin Eugenic şi Biopolitic published translations and discussions of the 1933 German law for the prevention of hereditarily diseased offspring (Gesetz zur Verhütung erbkranken Nachwuchses). ${ }^{68}$ Opinions varied.

\footnotetext{
${ }^{62}$ Ibid., p. 248. This is the first mention of a sterilization case in Romania that I have found. Regrettably, no archival material to substantiate this contention has surfaced as yet. That Parhon was, however, in favour of the sterilization of criminals is documented further in his discussion of the relationship between psychiatry and criminality. See C I Parhon, 'Raporturile dintre psihiatrie, ştiinţa dreptului şi criminalitate', Revista de Drept Penal şi Ştiință Penitenciară, 1936, 14 (8-9): 289-304.

63 "Această sterilizare se poate face numai când nivelul cultural al publicului va fi ridicat." Cahane, op. cit., note 59 above, p. 248.

${ }^{64}$ See Iuliu Moldovan, 'Proiectul Legii Sanitare şi de Ocrotire. Senatul, Sesiunea ordinară (prelungită), 1929-1930'. Moldovan, Iuliu, Personal File.

Romanian National Archives, Cluj.
}

\footnotetext{
${ }^{65}$ Mareş Cahane, 'Câteva date statistice în legătură cu ereditatea în bolile mintale. Este necesară sterilizarea unor categorii de bolnavi mentali?', Revista de Igienă Socială, 1935, 5 (10): 546-5, on p. 546.

66 "Deocamdată s-ar putea legifera: 1) avortul eugenic; sterilizarea voluntară; sterilizarea bolnavilor cronici în sensul moțiunii ce a fost redactată la congresul din 1931." Ibid., p. 554.

${ }^{67}$ Criticism was also voiced of the excesses of preventive sterilization in Germany. See, for example, V Ionescu, 'Sterilizarea', Axa, 6 Sept. 1933, 1 (17): 7; and 'Problema sterilizării preventive în Germania', Revista de Igienă Socială, 1932, 2 (10): 822.

${ }^{68}$ German sterilization law referred to the following medical categories: congenital feeblemindedness, manic-depressive psychosis, schizophrenia, epilepsy, Huntington's chorea,
} 


\section{Marius Turda}

In his commentary accompanying the Romanian translation, Banu, for instance, expressed his concerns over the "authoritarian" nature of the law, but agreed that its "main principles, intended to protect and develop the biological qualities of the race, entirely correspond to the ideal of protecting the highest biological values". 69 Another observer praised both Germany for considering "the biological capital as the supreme treasure of the nation" and the law for "assuring the priority of family and the ethnic body over the individual". ${ }^{70}$ Yet, he also criticized the law for exempting certain "degenerates" from sterilization, including such diverse categories as "moral degenerates, sexual offenders, internees of houses of correction, drug-addicts", and "prostitutes" and "vagabonds". 71

It was at this critical moment that the first book entirely devoted to eugenic sterilization was published in Romania. Written by Eugen Petit, jurist and legal adviser to the Court of Appeal in Bucharest, and Gheorghe Buzoianu, director of the Laryngological Hospital in Cluj, the book analysed eugenic sterilization from legal and medical perspectives. The juridical analysis—offered by Petit—reviewed European and North American experiences with eugenic sterilization, devoting considerable consideration to the Nazi law of 1933. While sympathetic to the idea of penal and therapeutic sterilization, Petit expressed his concerns about compulsory sterilization, especially if it were to be introduced in Romania: "No matter how many and serious arguments are invoked in favour of compulsory sterilization, we believe that in our case such a measure cannot be introduced as an ordinary law." 72 The existing Romanian penal code, Petit explained, expressly precluded any infringement of individual liberties. Accordingly, what was needed was a modification of the penal code whereby a sterilization law could be introduced. But was eugenic sterilization necessary in Romania? Petit found no reason why voluntary sterilization, for example, should not be introduced, with the caveat that it be offered to individuals with hereditary diseases, and only after a commission of specialists had agreed to the procedure. When it came to compulsory sterilization, however, Petit was decidedly against. ${ }^{73}$

Petit's legal discussion was followed by a translation of the complete text of Germany's new sterilization law, which served as the primary source of information for both the legal and the medical analysis. Buzoianu-the author of the second part of the book-provided a lengthy and erudite medical discussion of various techniques of sterilization for both men and women. Buzoianu was well acquainted with surgical procedures for sterilization, and offered a balanced synthesis of the latest developments

blindness, deafness, chronic alcoholism, and various physical deformities. See G Banu, 'Legea sterilizării în Germania', Revista de Igienă Socială, 1933, 3 (11): 550-4; and M Zolog and I Făcăoaru, 'Indicaţia şi legislaţia eugenică a sterilizării’, Buletin Eugenic şi Biopolitic, 1934, 5 (8-9-10): 186-92.

69 "Trebuie să recunoaştem că principiile de bază, menite a proteja şi a desvolta calităţile rasei, sub înfăţişare biologică, corespund întru totul idealului de protecţiune a valorilor cu calităţi maxime.” Banu, op. cit., note 68 above, p. 554.

70 "Capitalul biologic uman este socotit ca suprema bogăţie a naţiunii" and "Legea asigură prioritatea familiei şi a corpului etnic faţă de individ." I Făcăoaru, 'Legiurile recente pentru sterilizarea eugenică', Buletin Eugenic şi Biopolitic, 1934, 5 (8-9-10): 231-9, on p. 235.

${ }^{71}$ Ibid., p. 236.

72 "Oricât de multe şi serioase argumente s-ar invoca în favoarea sistemului sterilizării forțate, credem că la noi o asemenea măsură nu s-ar putea lua pe calea unei legi ordinare." Eugen Petit and Gheorghe Buzoianu, Sterilizarea din punct de vedere juridic şi chirurgical, Bucharest, 'Adevărul', 1934, p. 17.

73 Ibid., p. 21. 


\section{Debates on Eugenic Sterilization in Inter-war Romania}

in medical knowledge. Most importantly, he disseminated this to the general public in an accessible narrative, dismissing reservations and legitimate anxieties concerning the impact of sterilization on the individual's health, especially regarding sexual performance.

This book is just one example of a series of publications devoted to eugenic sterilization characterizing the late 1930s. Physicians still dominated the discussion, but the topic itself was no longer confined to the medical field. Leading Romanian physicians of the time perceived this as a threat to their scientific authority. Constantin Daniel, professor of gynaecology and director of gynaecological services at Colţea Hospital in Bucharest, for instance, discussed sterilization as an obstetric and gynaecological practice, without any comment on its social or national consequences. ${ }^{74}$ Another reaction came from the founder of the Romanian school of neurology, Gheorghe Marinescu, who, in 1935, published his extensive study on the relationship between heredity and eugenics. ${ }^{75}$

Marinescu's article deserves further attention. In addition to its scientific discussion of heredity and genetics, it provides two important details about eugenic sterilization in Romania. The first refers to a questionnaire sent by the Nazi government to various countries, including Romania, both to test their commitment to eugenics and to survey the condition of their hospitals. Some of the questions were directly related to sterilization:

Do laws or legal decisions exist with respect to the prevention of hereditary diseased offspring, to the encouragement of those hereditarily healthy, and especially of those hereditarily healthy with many children? ... What are the reasons for sterilization? Are they eugenic, medical, social? On what type of decision is sterilization based: judicial, sanitary policy, voluntary? Is sterilization performed itinerantly [by mobile stations]? What methods are used? Are those sterilized kept under observation after their release? Do card indexes about sterilization exist? When was sterilization introduced, and how many individuals were sterilized by the end of $1934 ?^{76}$

The Romanian response (which Marinescu had prepared with Banu) was, as he confessed, "evasive, because, in reality, in Romania systematic and co-ordinated measures to encourage healthy elements and prevent the development of unhealthy ones, antisocials, etc., had not been introduced" ${ }^{77}$ A new national programme of biological

\footnotetext{
${ }^{74}$ C Daniel, 'Sterilizarea operatorie la femeie', România Medicală, 1930, 8 (12): 169-70.

${ }^{75} \mathrm{G}$ Marinescu, 'Despre hereditatea normală şi patologică şi raporturile ei cu eugenia', Memoriile Secțiunii Ştiinţifice, 1936, 3 (11): 1-85.

76 "Ce legi sau deciziuni s-au luat cu privire la prevenirea progeniturii eredo-bolnave, a favorizării eredo-sănătoşilor şi mai cu seamă a celor eredosănătoşi cu mulţi copii? ... Pentru ce motiv se procedează la sterilizare? Din punct de vedere eugenic, medical, social? Pe baza căror hotărîri se procedează la sterilizare: judiciare, de politică sanitară, după cererea proprie, voluntară? Se sterilizează şi ambulant? Ce metode se întrebuinţează? Se continuă observarea celor sterilizaţi şi după ieşire? Se ţin cartoteci privitoare la sterilizare? De când s-a introdus sterilizarea şi câte
}

persoane au fost în total sterilizate până la sfârşitul anului 1934?" Ibid., p. 70.

77 "Răspunsul nostru, în colaborare cu Dr G Banu, a fost mai mult evaziv pentru că, în realitate, nu s-au luat la noi măsuri sistematizate şi coordinate pentru ridicarea elementelor sănătoase ale neamului nostru şi a se împiedica desvoltarea elementelor bolnave, asociale, etc." Ibid., p. 71. I have not so far located the German questionnaire or the Romanian response in the archives.Yet, Stefan Kühl's discussion of the foreign reception of Nazi race policies, and especially of various reports published by the Racial Office of the National Socialist Party in 1935, implies that such a questionnaire was circulated. See Stefan Kühl, The Nazi connection: eugenics, American racism, and German national socialism, Oxford University Press, 1994, pp. 89-90. 


\section{Marius Turda}

rejuvenation based on eugenic principles was consequently drafted, following the establishment in 1935 of the Royal Romanian Society for Heredity and Eugenics, with Marinescu as its president. ${ }^{78}$

It is at this point that the second detail pertaining to this discussion of eugenic sterilization arises. One of the statutes of the Society, written by Marinescu and Manliu, stipulated that its members "will propose a sterilization law for degenerated individuals, idiots, imbeciles, the feeble-minded, and criminals". ${ }^{79}$ None of the other eugenics societies in Romania had succeeded in including sterilization in their programme, although many of their members were declared supporters of it. ${ }^{80}$ Take the racial anthropologist and eugenicist Iordache Făcăoaru, for instance, also a member of the Eugenics and Biopolitical Section of the "Astra" Association in Transylvania and director of the Bioantropological Section of the Institute of Statistics in Bucharest. During a course on eugenics that he taught at the Institute for Hygiene and Public Health in Cluj in 1935, Făcăoaru remarked that compulsory sterilization was "one of the best methods to prevent the increase of degenerates of all categories". ${ }^{81}$ Such was the interest elicited by the topic that one of Făcăoaru's students, Ludwig Erich, decided to pursue it further in a doctoral dissertation. ${ }^{82}$

In the following years, Făcăoaru published more articles on degeneration, dysgenics and sterilization. Echoing Manliu's warnings about the degeneration of the Romanian nation-yet combining them with extensive knowledge of existing literature on heredity, eugenics and racial hygiene ${ }^{83}$-Făcăoaru declared that " 10 per cent of the [Romanian] population should not have offspring" ${ }^{84}$ This contention was related to his perception

\footnotetext{
${ }^{78}$ See Sabin Manuilă, 'Societatea regală română de eugenie şi studiul eredităţii', Sociologie Românească , 1936, 1 (5): 31-2; and 'Autorizarea de funcţionare, actul constitutiv şi statutele Societăţii Regale Române pentru Eugenie şi Studiul Eredităţii', Revista de Igienă Socială, 1936, 6 (4): 271-8. See also I Vasilescu-Bucium, 'Eugenia şi studiul eredității', Mişcarea Medicală Română, 1935, 8 (3-4): 169-74.

79 "Va propune o lege a sterilizării degeneraţiilor, idioţilor, imbecililor, debililor mentali, a

criminalilor." Marinescu, op. cit., note 75 above, p. 84 .

${ }^{80}$ The Romanian Royal Society of Eugenics and Heredity had two sections: one in Craiova (president: Ion Vasilescu-Bucium); the other in Chişinău (president: I Lepşi). The other eugenic societies in Romania were the Eugenics and Biopolitical Section of the "Astra" Association in Transylvania (established by Iuliu Moldovan in 1927), and the Demographic, Anthropological and Eugenics Section of the Romanian Social Institute (established by Sabin Manuilă in 1935). In 1939 these societies formed the Union of the Eugenics Societies in Romania under the presidency of Constantin Parhon, at the time also president of the International Latin Federation of Eugenics Societies. The Union was formed with the intention of organizing the second congress of the Federation, planned to be held in
}

Bucharest, 25-30 September 1939. See the announcement in Revista de Stiinte Medicale, 1939, 28 (3): 247-8. For reasons unknown, the congress did not take place.

81 "Introducerea sterilizării obligatorii ca metoda cea mai indicată pentru a stăvili creşterea numărului defectivilor de toate categoriile." I Făcăoaru, Curs de eugenie, Cluj, Institutul de Igienă şi Igienă Socială, 1935 , p. 67.

${ }^{82}$ Ludwig Erich, Problema disgenicilor (referintse speciale asupra situației disgenicilor de la noi), Cluj, Tipografia 'Record', 1937.

${ }^{83}$ Iordache Făcăoaru regularly wrote the 'Eugenic Notice-board' for the Bulletin, where he reported on debates on eugenic sterilization in countries as diverse as Latvia, Finland and Japan. See I Făcăoaru, 'Proiectul legii eugenice poloneze', Buletin Eugenic şi Biopolitic, 1936, 6 (4-5-6): 160-3, and 'Privire critică asupra legii finlandeze de sterilizare în comparaţie cu legea germană', Buletin Eugenic şi Biopolitic, 1937, 8 (10-11-12): 339-54, in which Făcăoaru compared Polish and Finnish sterilization laws with the German one, demonstrating the eugenic efficiency of the latter.

84 "Am putea spune că $10 \%$ din populaţia ţării noastre reprezintă un număr de persoane, care nu e de dorit să aibă urmaşi." I Făcăoaru, 'Inmulţirea disgenicilor şi costul lor pentru societate şi stat', 


\section{Debates on Eugenic Sterilization in Inter-war Romania}

that the increased number of dysgenic individuals jeopardized the biological future of the nation, leading Făcăoaru to support negative eugenic measures. Basing his analysis on famous dysgenic cases-for instance that of the Kallikak family in the United States-and on the Nazi racial laws, Făcăoaru contemplated "isolation or eugenic sterilization" so as "to make it impossible, by all means, for degenerates to reproduce". 85 He did not, however, merely imitate the ideological principles of the Nazi biological revolution. In addition to his support of the German sterilization law, Făcăoaru was similarly attracted to the model of national eugenics and biopolitics advocated by his mentor Iuliu Moldovan. Indeed, like many other eugenicists who worked with Moldovan at the Institute of Hygiene and Public Health in Cluj during the inter-war period, Făcăoaru, while not insensitive to racial arguments, refuted ideas of racial purity. ${ }^{86}$ Yet, he-like Manliu-persisted in appealing to the racial imagery of the Romanian nation in decline, a eugenic metaphor deemed especially problematic by those opposing eugenic sterilization.

\section{Opposition to Eugenic Sterilization}

Towards the end of the 1930s, discussions of eugenic sterilization were gradually forced into the realm of public debate by the increased interest in this topic of nonmedical professionals. As the neurologist Dumitru Enăchescu remarked, "Eugenic sterilization is a topic which today interests equally the biologist, the jurist and the sociologist." 87 Eugen Relgis, a sociologist, and Ion Vasilescu-Bucium, president of the juridical section of the Royal Romanian Society for Heredity and Eugenics in Craiova (the capital of Oltenia) were two such professionals.

Relgis, for instance, did not accept that dysgenic individuals had a right to exist: "These days", he maintained, "with the help of science, degenerates could be exterminated through euthanasia. It is, however, preferable, from all points of view, that degenerates should not be born, or, even better, not conceived. And, this is possible with the help of science: by sterilizing those who exhibit pathological characteristics or incurable diseases." 88 Following the French anarchist and neo-Malthusian Manuel Devaldès, Relgis further extolled the benefits of vasectomy, which he considered "a true revolution, not only in the field of eugenics but also in the social domain. We could even say that vasectomy is the basis of the regeneration of the human species." 89

Buletin Eugenic şi Biopolitic, 1935, 6 (4-5-6): $169-83$, on p. $179-80$.

85 "Să se facă imposibilă reproducerea degeneraţiilor indifferent pe ce cale, prin izolarea lor sau prin sterilizarea lor eugenică." I Făcăoaru,

'Familiile degenerate şi costul lor pentru societate şi stat', Buletin Eugenic şi Biopolitic, 1936, 6 (4-5-6): 214-21, on p. 221.

${ }^{86}$ Marius Turda, 'The nation as object: race, blood and biopolitics in inter-war Romania', Slavic Review, 2007, 66 (3): 413-41.

87 "Sterilizarea eugenică este o chestiune, care în momentul de faţă, interesează deopotrivă pe biolog, jurist şi sociolog." S D Enăchescu, 'Sterilizarea eugenică', Revista de Medicină Legală, 1936, 1 (2): 273-9, on p. 273.

88 " Azi, cu ajutorul ştiinţei, degeneraţi pot fi nimiciţi prin eutanasie. E însă preferabil, din toate privinţele, ca degeneraţii să nu fie născuţi-mai mult: să nu fie măcar concepuţi. Si, aceasta e posibil, cu ajutorul ştiinţei: prin sterilizarea acelora care prezintă caractere patologice sau boli incurabile.” Eugen Relgis, Umanitarism şi eugenism, Bucharest, 'Vegetarismul', 1935, pp. 28-9 (emphasis in the original).

89 "Să se considere vasectomia ca o adevărată revoluţie, nu numai în domeniul eugenismului, ci şi în acel social. Putem spune chiar că ea este la baza 


\section{Marius Turda}

The same argument about sterilization also underpinned Vasilescu-Bucium's assertion that social and biological progress could be achieved only by revising the Romanian penal code according to eugenic principles. ${ }^{90}$ In his view, the existing democratic legislation was detrimental to the biological improvement of the nation, for it failed to address deteriorating social and hygienic conditions. Only a penal code based on eugenics would provide the state with the necessary instrument for social and biological reconstruction. ${ }^{91}$ Vasilescu-Bucium also pointed out that at the 1935 XIth International Penal and Penitentiary Congress in Berlin, where eugenic sterilization and castration were discussed by both geneticists and penal experts, ${ }^{92}$ several suggestions had been made, including the need for eugenic sterilization of criminals. The Romanian representative, Vespassian Pella, together with those from France, Holland, Argentina, Belgium, Brazil, Poland, Yugoslavia, Spain, Portugal, Denmark and Egypt, finally accepted the proposal, although "with serious reservations" about its effectiveness. $^{93}$

Other authors, however, were more explicit in their attitudes against eugenic sterilization, bemoaning the lack of sufficient medical knowledge and public awareness. The founder of animal genetics in Romania, Gheorghe Constantinescu, for instance, warned that in the case of sterilization, "We need to wait for the results of many years of experience to be able to formulate a final point of view." 94 Iosif Leonida, a physician at the health centre in the village of Poseşti-Pămînteni (Prahova county), also expressed his reservations about the efficiency of eugenic sterilization in a rural country like Romania. While Constantinescu spoke on behalf of experimental biology, Leonida alluded to the general character of the Romanian nation, contrasting its "Latin mentality" with the "Anglo-Saxon mentality of countries where sterilization had been introduced". 95

regenerării speciei umane." Ibid., p. 64. See also Manuel Devaldès, La maternité consciente: le rôle des femmes dans l'amélioration de la race, Paris, Radot, 1927. For a discussion of Relgis's ideas of negative eugenics and his connection with Spanish anarchists, see Richard Cleminson, Anarchism, science and sex: eugenics in Eastern Spain, 1900-1937, Bern, Peter Lang, 2000, pp. 207-12.

${ }^{90}$ I Vasilescu-Bucium, 'Conceptul eugenic în legislaţia modernă’, Justiţia Olteniei, 1935, 16 (6-7): $41-2$.

${ }^{91}$ I Vasilescu-Bucium, 'Eugenia şi înoirile codului penal', Mişcarea Medicală Română, 1935 , 8 (5-6): 363-5. The article was also published in Justiţia Olteniei, 1935, 16 (10-11): 83-4; (13-14): 111-12; and in Pandectele Săptămânale, 1935 , 11 (26): 563-5.

${ }^{92}$ See 'Zum 11 Internationalen Kongreß für Strafrecht und Gefängniswesen', Zeitschrift für die gesamte Strafrechtwissenchaft, 1936, 55: 177-363. Section III of the congress dealt with 'Prevention', and sterilization was the first issue discussed. See J Lange, 'In welchem Falle und nach welchen Grundsätzen empfiehlt sich im modernen Strafsystem die Anwendung der Sterilisation durch Kastration oder durch Vasectomie oder Salpingectomie?', ibid., pp. 291-306. See also '11. Internationaler Kongreß für Strafrecht und Gefängniswesen’, Monatsschrift für Kriminalbiologie und Strafrecthsreform, 1935, 26 (5): 227-31; and Jan Simon Van der Aa (ed.), Proceedings of the XIth International Penal and Penitentiary Congress held in Berlin, August 1935, Bern, Bureau of the International Penal and Penitentiary Commission, 1937.

${ }^{93}$ I Vasilescu-Bucium, 'Criminologia şi eugenia', Revista de Medicină Legală, 1936, 1 (2): 84-90, on p. 88.

94 "Va trebui să aşteptăm rezultatele unei experienţe de mai mulţi ani, pentru a ne putea formula un punct de vedere mai decisive." G K

Constantinescu, Ereditate şi eugenie, Bucharest, Torouţiu, 1936, p. 91.

95 "Mentalitatea latină, care nu este de fel identică cu mentalitatea anglo-saxonă din ţările unde s-a introdus legea sterilizării." Iosif Leonida, 'Ce poate realiza practic eugenia la noi’, Mişcarea Medicală Română, 1935, 8 (5-6): 366-71, on p. 367. For a discussion of the differences between "Latin" and "Anglo-Saxon" eugenics, see Nancy Leys Stepan, "The hour of eugenics": race, gender, and nation in 


\section{Debates on Eugenic Sterilization in Inter-war Romania}

Writing in response to those eugenicists who claimed that the introduction of sterilization would contribute to the improvement of society, Leonida denied that such a radical eugenic measure could bring about social change. "The sterilization of criminals does not solve the problem of criminality", he claimed. ${ }^{96}$ Further, he believed that the enactment of legislation for eugenic sterilization and the introduction of prenuptial health certificates would have far-reaching social consequences, and lead to "numerous juridical controversies". ${ }^{97}$ Conceptual speculations on the positive effects of eugenic sterilization were also rejected as ineffective: "theoretical and academic discussions cannot achieve anything practical". ${ }^{98}$ Leonida insisted that only an improvement in Romania's economic situation could reduce illiteracy and alcoholism. Once prosperous, the rural population would become aware of the importance of hygiene, and eugenic sterilization would then be rendered "futile". Ultimately, Leonida minimized the importance of heredity, stating that mental and physical illnesses were likely to cause most immediate biological damage to the individual concerned rather than influence the genetic heritage of generations to come.

This scepticism about eugenic sterilization was further articulated by a psychiatrist at the Central Hospital in Bucharest, Grigore Odobescu. In Eugenie pentru neamul românesc (Eugenics for the Romanian Nation), Odobescu argued that in Romania "neither the voluntary sterilization practised in Switzerland, nor the social prophylactic sterilization practised in the US will be received favourably". ${ }^{99} \mathrm{He}$ did, however, accept that eugenic sterilization would be justified in "some cases, such as for those suffering from neuropsychotic disorders (those retarded, incurables especially), those who must be interned for life", and "those suffering from critical hereditary diseases". ${ }^{100}$ As a general rule, however, eugenic sterilization was not encouraged. "Degenerates" in Romania, Odobescu continued, were largely the result of ruinous economic and hygienic conditions. Among the most important causes of degeneration, he identified poor nutrition, a total lack of hygiene and rampant contagious diseases but not, significantly, hereditary diseases. ${ }^{101}$ Contrary to Manliu's grim diagnosis of a nation crippled by hereditary degeneration, Odobescu believed there were numerous examples that proved the "wonderful quality of the biological substance" intrinsic to the Romanian nation. What was needed, therefore, was "the education of the masses". Such an educational programme would not only increase economic and social standards, more vitally, it would "improve the biological condition" of the population. This was, he concluded, the "eugenic policy most suited to our country and nation". ${ }^{102}$ Ultimately, Odobescu

Latin America, Ithaca, Cornell University Press, 1991, pp. 189-92.

96 "Sterilizarea criminalilor nu rezolvă chestia criminalităţii." Leonida, op. cit., note 95 above, p. 368 .

${ }^{97}$ Ibid., p. 370.

98 "Nu cu discuăţii teoretice şi academice se poate realiza ceva practic la noi." Ibid.

99 "Credem că n-ar găsi la noi o atmosferă favorabilă nici sterilizarea facultativă practicată în Elveţia şi nici sterilizarea profilactică socială ca în America." Grigore Odobescu, Eugenie pentru neamul românesc, Bucharest, Monitorul Oficial şi Imprimeriile Statului, 1936, p. 12.

100 "Totuşi o indicaţie bine justificată ar găsi şi la noi sterilizarea eugenică în anumite cazuri, precum: la bolnavii neuro-psihici (alienaţii, mai ales incurabili), atât la cei ce trebuesc internaţi pentru totdeauna ...; la bolnavii cu boli hereditare grave." Ibid.

${ }^{101}$ Ibid., pp. 12-14.

102 "Aceasta constitute pentru ţara şi neamul nostru metoda eugenică cea mai naturală şi eficace." Ibid., p. 15. 


\section{Marius Turda}

believed the Romanian nation could be perfected by educational, social, and agricultural reforms rather than by introducing biological eugenic policies.

Odobescu pursued the same arguments further in Politica eugenică (Eugenic Policy). In this instance, he specifically connected the implementation of negative eugenics in Germany with the Nazi regime, arguing that "none of the methods applied elsewhere would bring us the desired results; they would be ineffective for our particular problems". ${ }^{103}$ Any introduction of eugenic policies in Romania should, therefore, take into consideration local specificities. Rather than eugenic sterilization, Odobescu offered another solution to social decline, insisting that the physical and mental health of the Romanian peasantry could be the source of national rejuvenation. In other words, Romania's rural and agrarian environment protected her from forms of urban degeneration experienced by the industrialized countries of Western Europe. ${ }^{104}$

Leonida and Odobescu were not alone in suggesting that social and biological degeneration could be controlled by means other than eugenic sterilization. Enăchescu also believed that "there is no need for eugenic sterilization to protect our race from degeneration". ${ }^{105}$ This category of eugenicists was indeed careful to distinguish between the excesses of negative eugenics and other positive doctrines of biological improvement. In return, such sceptical attitudes were criticized by supporters of eugenic sterilization. Făcăoaru, for instance, deplored both Odobescu's lack of eugenic enthusiasm and Leonida's deficient knowledge of genetics and eugenics. In contrast to Odobescu, who declared that the Romanian public were not prepared to accept eugenic sterilization, Făcăoaru claimed it was the responsibility of "the spiritual leaders of the nation" to create a favourable "atmosphere" for the reception of this eugenic practice. Odobescu's dedication to raising medical and hygienic awareness in Romania was welcomed, but this was not "eugenics"; Făcăoaru categorized it as "curative and preventive medicine, demography, as well as the hygiene of the individual and the social education of the nation". 106

The degree to which these debates on sterilization had divided Romanian eugenicists became obvious during the VIIth International Congress of Anthropology and Archaeology held in Bucharest in 1937. The third section of the congress, devoted to heredity and eugenics, was presided over by the Dutch psychiatrist and eugenicist Gerrit Pieter

\footnotetext{
103 "Atunci ajungem imediat la concluziunea că nici una dintre metodele aplicate în alte părţi n-ar putea să ne aducă prin aplicarea ei integrală foloasele urmărite şi poate chiar obţinute în locul lor de origine; ele ar fi ineficace în privinţa relelor noastre specifice." Grigore Odobescu, Politica eugenică, Bucharest, Institutul de Arte Grafice 'Eminescu', 1936, p. 10.

${ }^{104}$ See the analysis offered by Daniel Pick, Faces of degeneration: a European disorder, c.1848-1918, Cambridge University Press, 1989.

105 "Pentru a pune la adăpost rasa noastră de o asemenea descendenţă, cred că nu este nevoie de o sterilizare eugenică." Enăchescu, op. cit., note 87 above, p. 279.
}

\footnotetext{
106 “Măsurile la cari rămâne dl. Dr. Odobescu sunt nu numai necesare, dar urgente, decât că tratamentul bolilor infecţioase, îmbunătăţirea economică a poporului, combaterea mortalităţii, pedepsirea proxenenţilor, etc., înseamnă medicină curativă, preventivă, demografie, educaţie igienică individuală şi socială a poporului, dar aceste propuneri n-au nimic de a face cu eugenia." I Făcăoaru, 'Reviste româneşti în schimb cu Buletinul', Buletin Eugenic şi Biopolitic, 1936, 7 (3-4): 131. For Odobescu's and Leonida's reactions, see Odobescu, op. cit., note 99 above, pp. 11-14; and Iosif Leonida, 'Eugenie sau etnologie? (O confuzie şi un răspuns)', Mişcarea Medicală Română, 1935, 8 (5-6): 692-8.
} 


\section{Debates on Eugenic Sterilization in Inter-war Romania}

Frets. ${ }^{107}$ It was here that Vasilescu-Bucium argued, once again, for the inclusion of negative eugenic measures in the Romanian penal code in order to counteract degeneration and anti-social behaviour. ${ }^{108}$ His paper was succeeded by a lively discussion between those in favour of voluntary sterilization and those insisting on the need for compulsory sterilization. Marinescu, for instance, reaffirmed what he had said in his 1935 article on eugenics, agreeing with voluntary sterilization in the case of hereditarily transmitted diseases, but rejecting compulsory sterilization for "social and religious reasons". ${ }^{109}$ Opposing this view was his former student, the psychiatrist Gheorghe Stroescu, according to whom: "Compulsory sterilization is the only way of preventing the reproduction of those with hereditary illnesses and of improving the race." 110 Basing his arguments on his medical experience in France and Germany, and contrasting the eugenic practices in these two countries, Stroescu conveyed his preference for the latter:

While voluntary sterilization can be applied to intelligent patients, it cannot be carried out on the mentally ill and imbeciles. In our case, compulsory sterilization is the only means to prevent the continual increase of the feeble-minded, especially in isolated villages in the mountains. Voluntary sterilization proved inefficient in countries where it has been applied. ${ }^{111}$

Endorsing Stroescu's view, Făcăoaru stated that "voluntary sterilization was ineffective". He therefore suggested that, in order to reconcile the two perspectives, the following motion be submitted to the participants: "The third Section presided over by Mr Frets, having declared that voluntary sterilization produced no effect in the countries where it has been applied, proposes that eugenic sterilization be made obligatory and coercive." This was, however, a formulation that Marinescu found too drastic, suggesting instead: "The third Section presided over by Mr Frets proposes that eugenic sterilization is applied with prudence and only with the consent of the patient or his family."112

${ }^{107}$ G P Frets was president of the Nederlandsche Eugenetische Federatie and of the Human Heredity Committee. In this latter capacity he participated at the 1934 meeting of the International Federation of Eugenics Organizations held in Zurich where the Nazi sterilization law was discussed. See 'Compte Rendu de la XIe Assemblée de la Fédération Internationale des Organisations Eugénique', Revue Anthropologique, 1935, 45 (1-3): 78-92.

${ }^{108}$ I Vasilesco-Bucium, 'Tendances eugéniques dans le nouveau code penal roumain Carol II', XVIIe Congrès International d'Anthropologie et d'Archéologie Préhistorique, Bucarest, Imprimere Socec, 1939, pp. 678-81. That the Romanian penal code was in the process of accommodating the suggestions made by eugenicists did not escape foreign observers, as illustrated by this report, written by B Steinwaller, 'Rumänische Strafrechts- und Strafprozeßrechtsreform', Monatsschrift für Kriminalbiologie und Strafrechtsreform, 1938, 29 (5): 249-52. My thanks to Christian Promitzer for drawing my attention to this article.

109 'Discussions', in Vasilesco-Bucium, op. cit., note 108 above, p. 680.

\footnotetext{
110 “L'unique moyen pour empécher la
} multiplication des maladies héréditaires et pour améliorer la race est la sterilisation obligatoire." Ibid., p. 682 .

111 "Si la stérilisation facultative peut etre appliquée chez les malades intelligents, elle reste sans effet chez les malades mentaux et les imbéciles. Chez nous la stérilisation obligatoire est le seul moyen pour empécher l'extension incéssante des débiles mentaux, qui se sont surtout multipliés dans les villages plus ou moins isolés des montagnes. La stérilisation facultative est restée inefficace dans les pays ou elle a été appliquée." Ibid.

112 "La III-ème Section presidé par M. Frets, propose le voeu que la stérilisation practiquée dans un but eugénique soint appliquée avec prudence et seulement avec le consentement du malade ou sa famille." Ibid. This was a view endorsed by Frets as well. On Frets's ideas of sterilization, see Henny Brandhorst, 'From neo-Malthusianism to sexual reform: the Dutch section of the World League for Sexual Reform', J. Hist. Sex., 2003, 12 (1): 38-67. 


\section{Marius Turda}

Ultimately, it was Marinescu's position on voluntary sterilization that prevailed at the Congress.

Although all participants agreed that eugenic sterilization was essential to any national programme of biological improvement, the moderate view triumphed. Despite Stroescu's and Făcăoaru's escalating rhetoric, in 1937 there was still an intense debate on which form of eugenic sterilization was justifiable or desirable. Admittedly, the outspoken opposition to eugenic sterilization proposed by Leonida and Odobescu was not shared by prominent scientists like Marinescu; but neither was he persuaded by the arguments presented by Vasilescu-Bucium, Stroescu and Făcăoaru. Although more pragmatic than both opponents and supporters of eugenic sterilization, Marinescu did not specify which category of individuals would be subjected to voluntary sterilization, much less the legal and medical reasons required.

At about the same time, however, eugenic discourse in Romania underwent significant changes, largely under the influence of the radicalization of the political landscape. Conceptually, the discussion on eugenic sterilization was also drifting towards nationalist manipulations of ethnic aggressiveness, as ideas of national biology and racial protectionism were increasingly voiced by Romanian eugenicists.

\section{The Biology of Race}

The theme of national regeneration appealed particularly to Banu. Other eugenicists, most notably Manliu and Făcăoaru, were also influenced by racial hygienic ideas, but Banu was consistent in creating a corpus of writings in which eugenics and race were deeply connected. In 1935, he presented these ideas during one of his first public lectures suggestively entitled 'Eugenie, ereditate, rasă' (Eugenics, Heredity, Race) offering, in a condensed form, both a general history of eugenics and a racial history of the Romanian people. ${ }^{113}$ The efficient eugenic measures Banu enumerated were "abortion, segregation and prophylactic sterilization". Segregation and sterilization overlapped slightly, as both addressed the same categories of degenerates and anti-socials, namely those considered to be feeble-minded, psychopaths, epileptics, but also criminals and alcoholics. Ideally, Banu concluded, these types of people should all be subjected to "voluntary sterilization". ${ }^{114}$ In 1936, he further differentiated between two categories of eugenic measures: "Some immediate, with the aim of purifying a society instantly; others longterm, which slowly improve the biology of the community, generation after generation, diminishing the number of dysgenic elements, preventing the reproduction of worthless individuals." Among the "long-term" measures, Banu listed: "Isolation of dysgenic elements, namely segregation; then voluntary sterilization of those hereditarily incurable in order to prevent the reproduction of degenerates; and finally - as a radical measure-castration, especially of recidivist criminals." ${ }^{115}$ These ideas were then

\footnotetext{
${ }^{113}$ G Banu, 'Eugenie, ereditate, rasă', Revista de Igienă Socială, 1935, 5 (2): 102-7.

${ }^{114}$ Ibid., pp. 106-7.

115 "Izolarea elementelor deficiente, adică segregarea; apoi sterilizarea preventivă a elementelor profund tarate, spre a împiedica procrearea de non-
} valori; în fine-ca măsură radicală-castrarea, în
special a criminalilor recidivişti." G Banu,
'Certificatul medical prenupţial', Revista de Igienă
Socială, 1936, 6 (5): 281-300, on p. 289 (emphasis in
the original). 


\section{Debates on Eugenic Sterilization in Inter-war Romania}

refined to include five "immediate" measures: "eugenic census", "segregation", "sterilization", "castration", and "the protection of worthy elements". 116

If Moldovan and Odobescu's ideas of eugenics were related to the concept of the nation, Banu advocated instead the biology of race. To be sure, both positions endorsed improving the hygienic and eugenic conditions of the nation, but the latter-which imitated German racial hygiene-extended the domain of medical expertise to cover "racial" characteristics of the population. Following the German racial hygienist Alfred Ploetz, Banu declared: "Racial hygiene-a vast ensemble of extremely diverse concerns-derives from a science of even greater amplitude: the biology of race."117

In 1939, Banu published L'hygiène de la race, arguably the most sophisticated account of racial hygiene written by a Romanian eugenicist. ${ }^{118}$ In this book, Banu reiterated some of the arguments discussed in his previous articles, but this time his analytical repertoire was markedly improved: he offered both a solid theoretical discussion of heredity, and proposed concrete solutions for the biological improvement of the race. The sixth section of the book focused on "principles and methods for the normalization of the race". The foundation of Banu's eugenic philosophy lay in the suggestion that hygienic values and racial improvement were closely linked. In order "to normalize the race"- that is to protect its purity-various methods would be employed to "maintain and increase the normal elements of the race, and eliminate from the heart of the social organism elements which are deficient, physically and mentally". Special emphasis was placed on some of these methods, including "practical and theoretical investigations of heredity; biological and hereditary statistics; the study of family genealogies, the biological and hereditary status of the population, and the demographic evolution of communities". ${ }^{119}$

Preventive sterilization, like the prenuptial health certificate and segregation, was deemed one of the "socio-biological measures" required to bring about the "normalization of the race". Banu also engaged with two dissenting voices: one based on rationality, which condemned sterilization as an "encroachment on the rights of the individual"; and another, based on Christian morality, which "opposed the control of heredity". ${ }^{120}$ While some of the objections raised by "moralists and the representatives of the Church" were legitimate, Banu contended, none the less, that the scientific arguments justifying preventive sterilization were overwhelming. For instance, penal codes should be devised according to "the principle of social protection" rather than reflecting the "dogmas of liberal orthodoxy". ${ }^{121}$ Eugenic sterilization, by its nature, bore significant implications for the state as it offered a means by which to cut expenditure and re-invest in other public sector areas rather than offering treatment and protection to perceptibly dysgenic social groups. But, Banu continued, preventive sterilization was, "first and foremost, of biological

\footnotetext{
${ }^{116} \mathrm{G}$ Banu, 'Principes d'un programme d'hygiène de la race', Revista de Igienă Socială, 1936, 6 (10): $582-4$.

117 'L'hygiène de la race, vaste ensemble de problèmes extrêmement variés, dérive, à son tour, d'une science de plus d'envergure encore: la biologie de la race." Ibid., p. 577.

${ }^{118} \mathrm{G}$ Banu, L'hygiène de la race. Etude de biologie héréditaire et de normalisation de la race, Paris and Bucharest, Masson, 1939.
}

\author{
119 “L'étude théorique et pratique de l'hérédité, la \\ statistique biologico-héréditaire, l'étude des arbres \\ généalogiques, le statut biologico-héréditaire de la \\ population, l'évolution démographique des \\ collectivités." Ibid, p. 256. \\ ${ }^{120}$ Ibid., p. 293. \\ ${ }^{121}$ Ibid., p. 294.
}




\section{Marius Turda}

importance: it concerned the purity and the vital value of the race". ${ }^{122}$ The target, therefore, was to work towards a programme of biological rejuvenation in which relationships between the individual and the dominant racial community were mutually advantageous. He stressed that the sterilization of "pathological individuals", such as "imbeciles, idiots, epileptics, criminals, and those affected by diverse psychoses", as well as individuals suffering from syphilis, tuberculosis, and leprosy should be seen as the necessary formula for the conservation and improvement of the race. ${ }^{123}$

Banu's discussion of eugenic sterilization is symptomatic of the theoretical level reached by eugenicists in Romania, illustrating the weaknesses and inconsistencies of previous proposals, as well as an overarching perspective which was no less medical than social, political and national. Closely associated with this eugenic quest for comprehensive solutions to social problems were debates on authoritarian projects of national renewal, especially after the territorial losses of $1940 .{ }^{124}$ In the unsettling war period, these concerns with the national body took a distinctively racist turn: if previously eugenic sterilization targeted individuals suffering from diverse medical conditions, it now focused on the source of national degeneration posed by ethnic minorities. ${ }^{125}$

\section{Eugenic Sterilization as Political Discourse}

By the early 1940s, there were clear signs that much of the medical scepticism surrounding eugenic sterilization a decade earlier had been dispelled. As in Fascist Italy and Nazi Germany, various forms of radical biopolitics emerged in Romania that endorsed the idea of a totalitarian state as the epitome of Romanian ethnic supremacy. And like racial hygienists elsewhere, Romanian eugenicists adopted and championed principles of ethnic re-engineering and social segregation.

Although many eugenicists opposed marriages between Romanians and other ethnic minorities (especially in the Banat and Transylvania) none of them argued for the sterilization of the Jews, the Hungarians or the Germans. ${ }^{126}$ Yet, one ethnic group was particularly signalled out for its otherness and the "dysgenic" danger it posed to the Romanian majority: the Roma. ${ }^{127}$ In 1940, outlining the "racial problem in Romania", the demographer and director of the Central Institute of Statistics in Bucharest, Sabin Manuilă, identified the Jews and the Roma as standing outside of, and in opposition to, the Romanian national body. His argument rested almost exclusively on a racial representation of their social and ethnic functions. The Jews, for instance, were, "the

\footnotetext{
122 "Les indications de la stérilisation préventive sont, en premier lieu, d'ordre biologique: il s'agit de la pureté et de la valeur vitale de la race." Ibid., p. 297.

${ }^{123}$ Ibid., pp. 297.

${ }^{124}$ In 1940 Romania lost Bessarabia and northern Bukovina to the USSR, northern Transylvania to Hungary and southern Dobrudja to Bulgaria.

${ }^{125}$ Marius Turda, 'Fantasies of degeneration: some remarks on racial anti-Semitism in inter-war Romania', Studii Iudaice, 2003, 3: 336-48.

${ }^{126}$ There were a few maverick voices nevertheless. In 1940, the racial anti-Semite Toma Petrescu suggested that "the bastards resulting from
}

\author{
mixed marriages [between Jews and Romanians] \\ should be forcibly sterilized". ("Copiilor bastarzi \\ proveniţi din aceste casătorii mixte să li se aplice \\ sterilizarea forţată.") Toma Petrescu, Ni se pierde \\ neamul. Activitatea jidanilor impotriva naţiei \\ româneşti, Bucharest, Cugetarea, 1940, p. 37. \\ ${ }^{127}$ According to the 1930 Census there were \\ 262,501 Roma in Romania. 221,726 (84.5 per cent) \\ lived in rural areas, and 40,775 (15.5 per cent) in \\ urban areas. See Sabin Manuilă, Studiu etnografic \\ asupra populaţiei României, Bucharest, Editura \\ Institutului Central de Statistică, 1940, pp. 34-7.
}




\section{Debates on Eugenic Sterilization in Inter-war Romania}

most important social problem, the most sensitive political problem and most serious economic problem of Romania". But they "[did] not constitute a racial problem as racial mixing between Romanians and Jews occurs very rarely". ${ }^{28}$ The Roma, on the other hand, represented "the most important, sensitive and serious racial problem of Romania". ${ }^{129}$ They had mixed with the Romanians in villages and urban slums, thus creating a new racial hybrid, which in turn, infiltrated all spheres of life. Not surprisingly, Manuilă's assessment was meant to indicate a racially textured national drama: "The mixing of Gypsy with Romanian blood is the most dysgenic occurrence affecting our race." ${ }^{130}$ A year later, he framed his ideas of miscegenation through the familiar trope of eugenic sterilization: "Dysgenic, undesirable individuals should be pursued until they have all been sterilized." 131

Other authors agreed. The Orthodox theologian and professor at the Theological Academy in Sibiu (Transylvania), Liviu Stan, complained that contrary to their racial philosophies "neither National Socialism nor Fascism" had introduced a "racial policy towards the Gypsies", erroneously assuming that in Germany and Italy the "centre of infection and degeneration represented by the Gypsies" was non-existent. ${ }^{132}$ Such a policy was, however, imperative in Romania, where "racial promiscuity between Gypsies and Romanians", especially in the southern regions, resulted in the moral and biological degeneration of the latter. Like Manuilă, Stan perceived the Roma as having caused more "biological damage" to the Romanian racial body than the Jews, suggesting as "prophylactic measures" their "segregation" and the "prohibition of marriage between Gypsies and Romanians". ${ }^{133}$ Stan's racial policy towards the Gypsies served both moral and biological purposes, and he did not hesitate to present it as part of the glorious destiny that God had planned for Romanians.

It was evidently in response to such "racial fears" that the sterilization of the Roma was put forward. Gheorghe Făcăoaru, Iordache's brother, suggested, for instance, that:

Nomadic and semi-nomadic Gypsies be interned in camps. There their clothes will be changed; they will be shaved, receive a haircut and sterilized. To cover the costs of their maintenance, they should do forced labour. We will be rid of them from the first generation. Their place will be taken by national elements, capable of disciplined and creative work. Sedentary Gypsies will be sterilized at home, so that within a generation the place will be cleansed of them. ${ }^{134}$

\footnotetext{
128 "Problema evreiască poate fi definită ca cea mai importantă problemă socială, cea mai acută problemă politică şi cea mai gravă problemă economică a României. Ei nu constituesc o problemă rassială, pentru ca amestecul de rassă între Români şi Evrei este foarte rar." Sabin Manuilă, 'Problema rassială a României', România Nouă, 1940, 7 (41): 5.

129 "Problema ţigănească este cea mai importantă, acută şi gravă problemă rassială a României.” Ibid.

130 “'Amestecul ţigănesc în sângele românesc este cea mai disgenică influenţă care afectează rassa noastră." Ibid.

131 "Stânjenirea disgenicilor, a indezirabililor trebue să meargă până la completa lor sterilizare." Sabin Manuilă, "Acţiunea eugenică ca factor de
}

politică de populaţie', Buletin Eugenic şi Biopolitic, 1941, 12 (1): 1-4, on p. 2.

${ }^{132}$ L Stan, 'Rasism faţă de ţigani', Cuvântul, 1941, 18 (92): 1-2, on p. 1.

${ }^{133}$ Ibid., p. 2.

134 “Ţiganii nomazi şi semi-nomazi să fie internaţi în lagare de muncă forţată. Acolo să li se schimbe hainele, apoi să fie raşi, tunşi şi sterilizaţi. Pentru a se acoperi cheltuielile cu întreţinerea lor, trebuesc puşi la muncă forţată. $\mathrm{Cu}$ prima generaţie am scăpat de ei.

Locul lor va fi ocupat de elemente naţionale capabile de muncă ordonată şi creatoare. Cei stabili vor fi sterilizaţi la domiciliu, pentru ca în cursul unei generaţii să fie curăţit locul şi de ei." G Făcăoaru, Familia şi statul biopolitic, Bucharest, Bucovina, 1941, p. 17 (emphasis in the original). 


\section{Marius Turda}

In addition to the declared programme of racial purification, sterilizing the Roma was presented as a cost-saving solution in a period of economic depression: "The state spends almost a third of its budget on the maintenance of hospitals and various institutions of social assistance and vice squads, yet the social dirt increases daily. There is an easy solution to this: evil must be cut out at the roots and not cultivated." 135

These examples indicate how eugenic sterilization became sanctioned by a version of ethnic nationalism which was at the centre of the biopolitical programme envisioned by the Iron Guard. The sociologist Traian Herseni made this connection clear: "Dysgenic individuals must not be allowed to reproduce; inferior races should be completely isolated from the [Romanian] ethnic group. The sterilization of certain categories of individuals must not be conceived stupidly as a violation of human dignity but as a tribute to beauty, morality, and perfection." 136 The support given to sterilization by prominent intellectuals like Herseni and Manuilă was consonant with the new ideological goals of Romanian eugenics emerging after 1940, as well as with the general tendency within the Romanian government of Marshal Ion Antonescu (1941-44) towards national homogenization and ethnic purification. ${ }^{137}$ Although the Jews were the main target of these policies, the Roma too were subjected to deportation and starvation. ${ }^{138}$

The way in which the discourse on eugenic sterilization evolved from its beginning as an appendix to medical debates on natality and reproduction in the 1920s, to one of the tenets of fascist political philosophy in the 1940s is perfectly illustrated by two examples. The first is provided by Liviu Stan, who-complaining about the "dysgenic monsters" populating Romania—did not hesitate to declare:

Charitable action and social assistance have no sense, do not solve anything, and will continue for ever if the evil is not cut out at the root. Otherwise, such efforts are useless because they do not lessen people's misfortune but intensify it by extending it to those who could have a creative and liberating life instead of one of servitude to dysgenic individuals and miserable degenerates. ${ }^{139}$

Drawing on science and Orthodox Christianity, Stan developed a national theology in which the protection of the nation was dictated by God's will as revealed in eugenic

\footnotetext{
135 "Statul cheltueşte aproape o treime din bugetul său cu întreţinerea spitalelor şi a tot felul de instituţii de asistenţă socială şi poliţie de moravuri, şi cu toate acestea mizeria socială creşte pe fiecare zi. E o explicaţie şi o soluţie simplă: răul trebuie tăiat din rădăcină şi nu cultivat." Ibid., p. 18 (emphasis in the original).

136 "'Disgenicii trebuesc înlăturaţi de la reproducție, rasele inferioare trebuesc complet separate de grupul etnic. Sterilizarea anumitor categorii de oameni nu numai că nu trebuie privită prosteşte ca o încălcare a demnităţii omenești, dar ea este un elogiu adus frumuseţii, moralităţii şi în genere perfecţiunii." Traian Herseni, 'Rasă şi destin naţional', Cuvântul, 1941, 18 (91): 1-7, on p. 7.

${ }^{137}$ Vladimir Solonari, 'An important new document on the Romanian policy of ethnic cleansing during World War II', Holocaust and Genocide Studies, 2007, 21 (2): 268-97.
}

${ }^{138}$ Viorel Achim, The Roma in Romanian history, Budapest, Central European University Press, 2004; idem, Documente privind deportarea țiganilor in Transnistria, Bucharest, Enciclopedică, 2004; and Radu Ioanid, The Holocaust in Romania: the destruction of Jews and Gypsies under the Antonescu regime, 1940-1944, Chicago, Ivan R Dee, 2000.

139 “Acţiunea caritativă şi asistenţa socială nu au nici un rost, nu rezolvă nimic şi nu se va sfârşi niciodată, dacă nu i se mai seacă rădăcina răului care le reclamă. Altfel, e măcinare zadarnică de forţă fără a scădea nimic din nenorocirea oamenilor, ci înmulţind nefericirea prin extinderea ei şi asupra celor ce ar putea trăi o viaţă liberă şi creatoare, în loc de una de servitudine faţă de disgenici şi de nenorociţii degeneraţi." Liviu Stan, Rasă şi religiune, Sibiu, Tiparul Tipografie Arhidiecezane, 1942, p. 144. 


\section{Debates on Eugenic Sterilization in Inter-war Romania}

principles. This idea resonated perfectly with Manliu's call for the Orthodox Church's involvement in biological projects of national protectionism. Eugenics thus performed different and contradictory functions simultaneously.

Mihai Antonescu, the deputy prime minister and minister of foreign affairs between 1941 and 1944, is the second example. In 1941 Antonescu spoke of the "ethnic and political purification" of the population in Bessarabia and Bukovina, namely "the purification of our nation of those foreign elements foreign to its soul". ${ }^{140}$ There is no documentary evidence to suggest that Roma or Jewish communities were subjected to sterilization, either in Romania or in Transnistria, which Romanian troops occupied in 1941, and where much of the Holocaust of the Jews from Bessarabia and Bukovina took place. ${ }^{141}$ Yet, the brutalities perpetrated during the military occupation of Transnistria between 1941 and 1944 suggest convincingly that there was a connection between eugenic discourses of national purification and ideas of ethnic homogeneity. Whether eugenic nationalism or military strategies claimed precedence in Antonescu's endorsement of the Holocaust is, ultimately, of secondary importance, as both were infused with the same biological logic, mandating the elimination of those deemed different and inferior.

\section{Conclusions}

Reminiscing about his attempts to educate the Romanian public in the tenets of degeneration, eugenics, and sterilization, the gynaecologist Constantin Andronescu remarked sternly in 1943 that, in contrast to other European states and the United States, eugenic sterilization had still not been introduced in Romania, and he hoped that this impediment to the racial improvement of the nation would soon be removed. ${ }^{142}$ The reasons for this delay were twofold. Firstly, as this article has suggested, eugenicists themselves were divided over these issues. Some, like Baltazar, Constantinescu, Leonida and Odobescu, viewed eugenic sterilization with scepticism and argued skilfully against it; others, like Ygrec, Moldovan, Marinescu and Cahane, while endorsing voluntary sterilization were distrustful of radicals like Manliu, Făcăoaru, Stroescu and Banu, who argued for compulsory sterilization. Secondly, the Orthodox Church opposed any erosion of its traditional role as guardian of the nation, although some of its theologians, like Liviu Stan, developed a national theology in accordance with both eugenic and Christian principles.

The other argument relates to the nature of political decision making in Romania between 1920 and 1940. Despite intense debates, lecturing and lobbying, promoters of eugenic sterilization failed to secure the widespread support necessary for a sympathetic

\footnotetext{
140 "Purificarea Neamului nostru de toate acele elemente străine sufletului lui”. Mihai Antonescu, 'Directive şi îndrumări date inspectorilor administrativi şi pretorilor trimişi în Basarabia şi Bucovina', in Martiriul evreilor din România, 1940-1944. Documente şi mărturii, Bucharest, Hasefer, 1991, p. 139.

${ }^{141}$ In 1944 the ethnographer Ion Chelcea was still suggesting that certain Roma groups should be
}

\footnotetext{
"settled in an isolated region, transferred to Transnistria and, if necessary, sterilized" ("va trebui colonizat într-o parte mărginaşă a ţării, trecuţi peste Nistru, la caz sterilizaţi”). See Ion Chelcea, Ţiganii din România. Monografie etnografică, Bucharest, Editura Institutului Central de Statistică, 1944, p. 101.

${ }^{142}$ Constantin I Andronescu, Pentru ce ne îmbolnăvim? Noțiuni de patologie socială, Bucharest, 'Cartea Românească', 1943, p. 46.
} 


\section{Marius Turda}

government to enact legislation for eugenic sterilization. Yet, the concern with degeneration, dysgenics, and the health of the nation was as dominant in Romania as in countries where eugenic sterilization had been introduced. If in the 1920s and 1930s eugenic sterilization was predominantly defined as medical praxis, centred on individuals suffering from physical and mental illnesses, in the 1940s it became a political discourse identified with Romanian racial nationalism. The focus shifted from medical patients to ethnic categories deemed detrimental to the body of the Romanian nation and its racial future. In this respect, then, the goal of eugenic sterilization was the creation of a new nation through biological regeneration.

What this article demonstrates is that, as elsewhere in Europe, discourses on eugenic sterilization in Romania-expressed through an obsession with the body of the nation-were much more influential and diffuse than has been previously assumed. The tenacity of these discourses throughout the inter-war period made it possible for political leaders to speak during the war period in terms of protection and purification, and act accordingly. The vocabulary of eugenic sterilization thus overlapped with a parallel set of beliefs about racial and national decline, which served to amplify the vision of Romania as a country beset by internal and external enemies. Manliu's evocative phrase "to end the degeneration of a nation" received its ultimate expression not in the sterilization of the feeble-minded but in the deportation of Jews and Roma to the concentration camps. Underlying this assumption is the conviction that the exploration of links between eugenic discourses and practical politics continues to be crucial for a proper understanding of the success and failure of biopolitical ambitions to transform society in the twentieth century. ${ }^{143}$

\footnotetext{
${ }^{143}$ The history of eugenics can still-as Lesley A Hall has recently reminded us- "generate vibrant and exciting scholarship, by looking beyond a narrow and restrictive view of what eugenics meant to those who deployed the term, and how it fitted into much
}

broader early twentieth-century concerns over nation, state, national health, social welfare, citizenship and modernity." Lesley A Hall, 'Eugenics, sex and the state: some introductory remarks', Stud. Hist. Phil. Biol. Biomed. Sci., 2008, 39 (2): 177-80, on p. 180. 